\title{
Application of Vine-Shoot Chips during Winemaking and Aging of Malbec and Bonarda Wines
}

\author{
Martín Fanzone ${ }^{1,2, *(0)}$, Anibal Catania ${ }^{1}\left(\right.$, Mariela Assof ${ }^{1,2}\left({ }^{\circ}\right.$, Viviana Jofré ${ }^{1,2}$, Jorge Prieto ${ }^{1,2}(\mathbb{D}$, \\ Daniela Gil Quiroga ${ }^{2}$, Juan Lacognata Sottano ${ }^{2}$ and Santiago Sari ${ }^{1}$ \\ 1 Estación Experimental Agropecuaria Mendoza, Instituto Nacional de Tecnología \\ Agropecuaria (EEA Mendoza INTA), San Martín 3853, 5507 Mendoza, Argentina; \\ catania.anibal@inta.gob.ar (A.C.); assof.mariela@inta.gob.ar (M.A.); jofre.viviana@inta.gob.ar (V.J.); \\ prieto.jorge@inta.gob.ar (J.P.); sari.santiago@inta.gob.ar (S.S.) \\ 2 Centro de Estudios Vitivinícolas y Agroindustriales (CEVA), Universidad Juan Agustín Maza, \\ Av. Acceso Este, Lateral Sur 2245, 5519 Mendoza, Argentina; gilquirogadaniela@gmail.com (D.G.Q.); \\ juanilacog@gmail.com (J.L.S.) \\ * Correspondence: fanzone.martin@inta.gob.ar; Tel.: +54-926-146-73011
}

check for updates

Citation: Fanzone, M.; Catania, A.; Assof, M.; Jofré, V.; Prieto, J.; Gil Quiroga, D.; Lacognata Sottano, J.; Sari, S. Application of Vine-Shoot Chips during Winemaking and Aging of Malbec and Bonarda Wines. Beverages 2021, 7, 51. https:// doi.org/10.3390/beverages7030051

Academic Editor: Maria Carla Cravero

Received: 29 May 2021

Accepted: 13 July 2021

Published: 19 July 2021

Publisher's Note: MDPI stays neutra with regard to jurisdictional claims in published maps and institutional affiliations.

Copyright: (c) 2021 by the authors. Licensee MDPI, Basel, Switzerland. This article is an open access article distributed under the terms and conditions of the Creative Commons Attribution (CC BY) license (https:// creativecommons.org/licenses/by/ $4.0 /)$.

\begin{abstract}
The growing demand in recent years for sustainable wine production has led to the management of waste and by-products. Among them, vine-shoots could be used as additives comparable to the oak fragments widely employed in enology. This work analyzes the feasibility of applying vine-shoot chips during winemaking and the aging of Malbec and Bonarda wines from Mendoza (Argentina) and evaluates their chemical and sensory impact. Toasted (CHT) and untoasted (CHWT) vine-shoot chips obtained from a Bonarda vineyard were added in Malbec and Bonarda grapes during winemaking (Experiment A): C, control; CHWT, 12 g/L; CHT, 12 g/L. Furthermore, the same treatments were applied during aging ( $1 \mathrm{M}, 30$ days; $2 \mathrm{M}, 60$ days; $4 \mathrm{M}, 120$ days) to the finished wines under controlled conditions (Experiment B). The impact of vine-shoot chips during winemaking was different between varieties. For Malbec alone, CHT caused a significant decrease in tannins, anthocyanins, and polymeric pigments, and a modification of wine color. During aging, CHWT and CHT had an impact mainly at the sensory level, increasing the wine's complexity in terms of aromatic attributes and mouthfeel. In conclusion, the proposed technology could be a simple and economical tool for red wine production of high chemical and organoleptic quality.
\end{abstract}

Keywords: vine-shoot chips; Malbec; Bonarda; wines; phenolic composition; sensory analysis

\section{Introduction}

The circular economy stimulates agro-industrial waste recovery and utilization processes to minimize waste production, increase efficiency in the use of natural resources, add value to by-products, and contribute to the restoration of environmental, food, and health balances [1]. Agricultural and agro-industrial activities generate large volumes of waste and by-products, which translates into direct environmental impact problems and indirect problems related to disposal logistics and associated costs. The use of by-products represents a promising topic, in which it is essential to promote actions in research and development, transfer and extension, linkage, and public-private cooperation.

The wine sector is no stranger to this reality, with pomace being the major by-product of winemaking (20-25 kg/100 kg of grapes). In addition, the vine-shoots obtained from pruning are the main waste in viticulture $(\approx 93 \%)$, with an estimated annual world production of 1.4 to 2.0 tons per hectare [2]. Since a large proportion of this waste is left or burned in the field, with the environmental risks that this entails [3], it is necessary to look for new alternatives for its use. At the viticulture level, the potential application of vine-shoot extracts as biostimulants in vineyards to improve wine quality [4-6], and their action as bioplaguicides, have been proven [7]. At the chemical-enological level, some 
studies have characterized the volatile and non-volatile compositions of vine-shoot fragments from different cultivars [8,9], while others have evaluated the effect of post-pruning storage on vine-shoots' composition [10,11], the impact of the toasting process [11-13], and vine-shoots' suitability as an enological additive in model solutions and grape musts as a function of fragment size, toasting effect, dosage, and contact time [14,15].

Nowadays, the use of oak wood pieces (chips and staves) during the winemaking and aging processes is a common enological practice in several wine-producing regions, due to their interesting contribution of phenolic and volatile compounds [16-18]. Although oak chips are by-products of barrel manufacturing, the quantity generated is significantly less than vine-shoots pruned, and the costs higher. Interestingly, vine-shoots have comparable levels of volatile compounds (furanoids, benzenoids, terpenoids) and phenolics to oak wood, in addition to higher concentrations of trans-resveratrol and an absence of ellagitannins [11,13].

Argentina is an important wine-producing country in the southern hemisphere, with 214,798 ha of vineyards representing $\sim 3 \%$ of the global wine grape cultivation area [19]. Mendoza province has $\sim 70 \%$ of all vineyards, with the wine industry being one of its main economic development sources. Malbec and Bonarda (Vitis vinifera L.) are considered emblematic cultivars for winemaking, accounting for more than $55 \%$ of the red grapes produced in the country [19].

In this context, and due to the absence of scientific reports on the use of vine-shoots of the aforementioned varieties, the evaluation of their chemical-enological potential constitutes a promising strategy for their valorization within the wine chain. Thus, this work aimed to study the feasibility of applying vine-shoot chips during winemaking and aging of Malbec and Bonarda wines from Mendoza (Argentina) and to evaluate their chemical and sensory impact.

\section{Materials and Methods}

\subsection{Vine-Shoot Chips}

The plant material employed for evaluation as vine-shoot wood was obtained from an experimental cv. Bonarda (Vitis vinifera L.) vineyard, located in Luján de Cuyo $\left(33^{\circ} 00^{\prime} \mathrm{S}\right.$, $68^{\circ} 51^{\prime} \mathrm{W}$ ), Mendoza. Vine-shoots were pruned during winter (2019 season), 120 days after their grape harvest, with $20 \mathrm{~kg}$ collected and stored intact under controlled conditions (darkness, $15 \pm 3{ }^{\circ} \mathrm{C}, \mathrm{RH} 45-50 \%$ ) for three months [9]. After this time, the vine-shoots were manually cut into "chips" (particle size around 1.5-3 cm long, similar to oak chips) and half of them subjected to a toasting process in an air circulation oven (SanJor SL40ADF, Buenos Aires, Argentina) at $180^{\circ} \mathrm{C}$ for $45 \mathrm{~min}$, according to Cebrián-Tarancón et al. [11]. Toasted (CHT) and untoasted (CHWT) vine-shoot chips were stored at $0-4{ }^{\circ} \mathrm{C}$ until their application in winemaking and wine aging experiments.

\subsection{Experimental Design}

\subsubsection{Application of Vine-Shoots during Winemaking (Experiment A)}

Grapes of two red cultivars, Bonarda and Malbec (Vitis vinifera L.), were obtained from a commercial vineyard ( $32^{\circ} 59^{\prime} \mathrm{S}, 68^{\circ} 34^{\prime} \mathrm{W}$, Maipú, Mendoza, Argentina) and an experimental vineyard ( $33^{\circ} 00^{\prime} \mathrm{S}, 68^{\circ} 51^{\prime} \mathrm{W}$, Luján de Cuyo, Mendoza, Argentina), respectively, during the 2020 season. In both cases, grapes were hand-picked when they reached optimum phenolic maturity and showed these technological parameters: Bonarda, $25^{\circ}$ Brix, $5.5 \mathrm{~g} / \mathrm{L}$ of titratable acidity, $\mathrm{pH} 3.5$; Malbec, $24^{\circ}$ Brix, $5.0 \mathrm{~g} / \mathrm{L}$ of titratable acidity, $\mathrm{pH}$ 3.85. The grapes were crushed, destemmed (Metal Liniers model MTL 12, Mendoza, Argentina), sulfited (100 mg K ${ }_{2} \mathrm{~S}_{2} \mathrm{O}_{5} / \mathrm{kg}$ ), and the musts placed into 25-L food-grade plastic tanks. For each variety, a completely randomized design was applied (Scheme 1) consisting of three treatments by triplicate: C, control (destemmed grapes); CHWT, control + untoasted vine-shoot chips (12 g/L); CHT, control + toasted vine-shoot chips (12 g/L). The chips dosage applied was selected according to previous studies carried out with vine-shoots of other grape varieties [13,14]. Accordingly, 18 vinifications [two varieties (Malbec and 
Bonarda) $\times$ three treatments $(\mathrm{C}, \mathrm{CHWT}, \mathrm{CHT}) \times$ three replicates] were conducted by inoculation of the commercial yeast EC1118 (Lallemand, Montreal, QC, Canada), at $25 \pm 2{ }^{\circ} \mathrm{C}$, with a maceration length of 13 days. For cap management, two daily punch-downs (morning and afternoon, $1 \mathrm{~min}$ each) were applied. All tanks were controlled daily through the measurement of temperature and the weight loss of the fermenting systems. Once fermentation-maceration was completed, free-run wines were collected in $10 \mathrm{~L}$ glass carboys fitted with airlocks, adjusted to $45 \mathrm{mg} / \mathrm{L}$ of free $\mathrm{SO}_{2}$, and stored at $1-3{ }^{\circ} \mathrm{C}$ for 15 days to allow tartaric stabilization. Finally, the wines were racked off the lees, bottled $(750 \mathrm{~mL})$, and stored in a dark cellar at $12-15{ }^{\circ} \mathrm{C}$ until analysis. In all cases, the analyses of wine samples were completed in about one month.
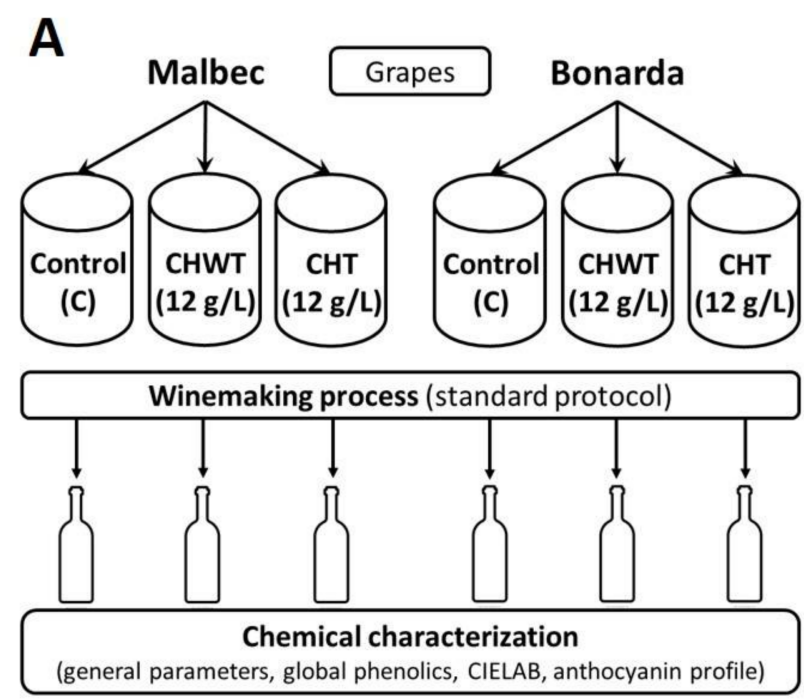

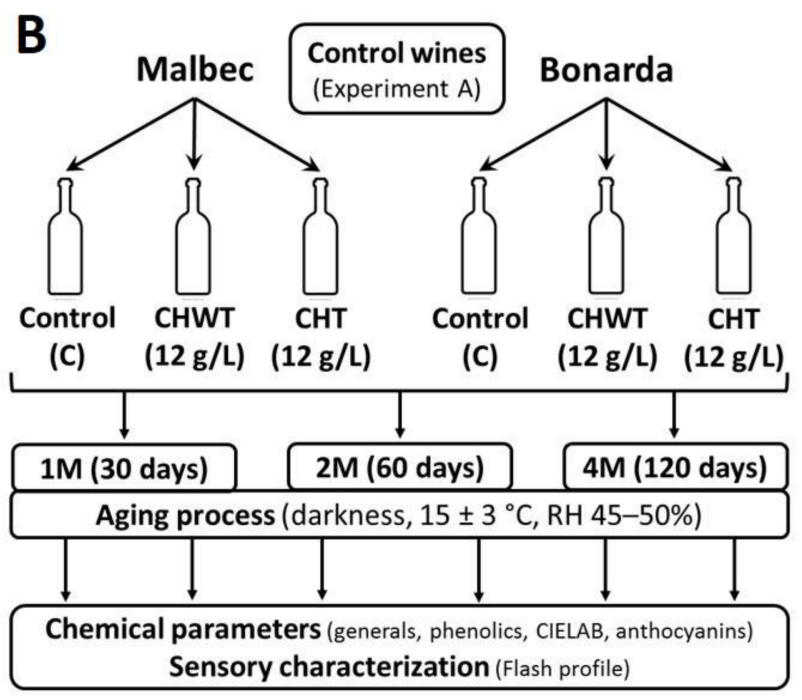

Scheme 1. Summary of experimental design with vine-shoots application in Malbec and Bonarda varieties during winemaking ((A) Experiment A) and aging ((B) Experiment B).

\subsubsection{Application of Vine-Shoots during Wine Aging (Experiment B)}

The use of vine-shoot chips as an aging additive was evaluated with Malbec and Bonarda control wines (C, Experiment A) using glass bottles ( $375 \mathrm{~mL}$, amber, screw-cap) as storage containers and independent experimental units. In both varieties, a factorial design was applied consisting of two factors (factor 1, aging time; factor 2, vine-shoot treatments) with three levels each, by triplicate. For factor 2: C, control (stabilized wine); CHWT, control + untoasted vine-shoot chips (12 g/L); CHT, control + toasted vine-shoot chips $(12 \mathrm{~g} / \mathrm{L})$. Factor 1 comprised three aging times (1M, 30 days; $2 \mathrm{M}, 60$ days; $4 \mathrm{M}, 120$ days) under controlled conditions (darkness, $15 \pm 3{ }^{\circ} \mathrm{C}, \mathrm{RH} 45-50 \%$ ). Once the established aging time was completed, the wine was immediately separated from the vine-shoot chips for each experimental unit, and chemical and sensory characterization was carried out. Consequently, 54 wines -27 Malbec (factor $1 \times$ factor $2 \times$ three replicates) and 27 Bonarda (factor $1 \times$ factor $2 \times$ three replicates) - were obtained (Scheme 1 ). At the first point of analysis $(1 \mathrm{M})$, all wines had completed malolactic fermentation spontaneously.

\subsection{Wine General Analytical Parameters}

Standard parameters including titratable acidity (tartaric acid, $\mathrm{g} / \mathrm{L}$ ), volatile acidity (acetic acid, g/L), malic acid (g/L), lactic acid (g/L), $\mathrm{pH}$, and alcohol content $(\% v / v)$ were determined as described by the International Organization of Vine and Wine [20] using an ALPHA FT-IR Wine Analyzer (Bruker Optics, Ettlingen, Germany) and an alcohol tester (Alcolyzer Wine ${ }^{\circledR}$; Anton-Paar GmbH, Graz, Austria). 


\subsection{Global Phenolic Composition and Color Parameters}

Wine samples were centrifuged $(11,000 \times g, 5 \mathrm{~min})$ and filtered through $0.45-\mathrm{mm}$ membranes (Microclar, Buenos Aires, Argentina) before analysis. Absorbance measurements were made with a Perkin-Elmer UV-Visible Spectrophotometer Model Lambda 25 (PerkinElmer, Hartford, CT, USA). Tannins were analyzed by protein precipitation [21]. Anthocyanins, small polymeric pigments (SPP), large polymeric pigments (LPP), and total polymeric pigments (SPP + LPP) were measured as previously described [21]. Ironreactive phenolics (total phenols) were analyzed following the method described by Heredia et al. [22].

For color characterization, the wine samples were analyzed by means of the CIELAB color space [23], following the recommendations of the Commission Internationale de L'Eclairage [24]. CIELAB parameters [ $\mathrm{L}^{*}\left(\right.$ lightness, 0 black and 100 white), $\mathrm{C}^{*}{ }_{\mathrm{ab}}$ (chroma, saturation), $\mathrm{h}_{\mathrm{ab}}$ (tone; red, green, yellow), and the $\mathrm{a}^{*} \mathrm{~b}^{*}$ (red/green; yellow /blue) coordinates] were calculated from the absorption spectra $(380-750 \mathrm{~nm})$ at $1 \mathrm{~nm}$ intervals using $1 \mathrm{~mm}$ path-length glass cells and distilled water as a reference, using the colorscience $\mathrm{R}$ package [25]. Color difference $\left(\Delta \mathrm{E}_{\mathrm{ab}}^{*}\right)$ was calculated as the Euclidean distance between two points $(1$ and 2$)$ in three-dimensional $\left(\mathrm{L}^{*} \mathrm{a}^{*} \mathrm{~b}^{*}\right)$ space. $\Delta \mathrm{E}_{\mathrm{ab}}^{*}\left(\mathrm{~L}^{*}{ }_{1}, \mathrm{a}^{*}{ }_{1}, \mathrm{~b}^{*} ; \mathrm{L}_{2}^{*}, \mathrm{a}_{2}, \mathrm{~b}^{*}{ }_{2}\right)$ $=\left[\left(\Delta \mathrm{L}^{*}\right)^{2}+\left(\Delta \mathrm{a}^{*}\right)^{2}+\left(\Delta \mathrm{b}^{*}\right)^{2}\right]^{1 / 2}$, where $\Delta \mathrm{L}^{*}=\mathrm{L}_{1}^{*}-\mathrm{L}_{2}^{*} ; \Delta \mathrm{a}^{*}=\mathrm{a}^{*}{ }_{1}-\mathrm{a}^{*}{ }_{2}$ and $\Delta \mathrm{b}^{*}=\mathrm{b}^{*}{ }_{1}-\mathrm{b}^{*}{ }_{2}$.

\subsection{Anthocyanins and Derived Pigments}

A Perkin-Elmer Series 200 high-performance liquid chromatograph equipped with a diode array detector, a quaternary pump, and an autosampler (HPLC-DAD; PerkinElmer, Shelton, CT, USA) was used for anthocyanin identification and the quantification of wine samples. Separation was performed on a reversed-phase Chromolith Performance C18 column $(100 \mathrm{~mm} \times 4.6 \mathrm{~mm}$ I.D., $2 \mu \mathrm{m}$; Merck, Darmstadt, Germany) with a Chromolith guard cartridge $(10 \mathrm{~mm} \times 4.6 \mathrm{~mm})$ at $25^{\circ} \mathrm{C}$. A gradient consisting of solvent A (water/formic acid, 90:10, $v / v$ ) and solvent $B$ (acetonitrile) was applied at a flow rate of $1.1 \mathrm{~mL} / \mathrm{min}$ from 0 to $22 \mathrm{~min}$ and $1.5 \mathrm{~mL} / \mathrm{min}$ from 22 to $35 \mathrm{~min}$ as follows: $96-85 \% \mathrm{~A}$ and $4-15 \% \mathrm{~B}$ from 0 to $12 \mathrm{~min}, 85-85 \% \mathrm{~A}$ and $15-15 \%$ B from 12 to $22 \mathrm{~min}$, and $85-70 \%$ A and $15-30 \%$ B from 22 to $35 \mathrm{~min}$. This was followed by a final wash with $100 \%$ methanol and re-equilibration of the column. Two milliliters of wine samples were filtered $(0.45-\mu \mathrm{m}$ pore size nylon membrane; Microclar, Buenos Aires, Argentina) and then $50 \mu \mathrm{L}$-aliquot was injected into the column. Diode array detection was performed from 210 to $600 \mathrm{~nm}$ and the quantification was carried out by peak area measurements at $520 \mathrm{~nm}$. The anthocyanin amount was expressed by using malvidin-3-glucoside chloride as the standard for a calibration curve $\left(R^{2}=0.99\right)$. Identification and confirmation of anthocyanin pigments were performed by HPLC-DAD/ESI-MS as described by Blanco-Vega et al. [26].

\subsection{Sensory Analysis}

The sensory technique used was Flash profile (FP) [27]. Two separate sessions were made for each variety and aging time (Experiment B). In the first session, the assessors were given an explanation about FP and they were asked to individually generate the sensory characteristics that best described the differences among the wines. This global list was presented as an aid tool to allow assessors to update their own list if desired but it was not aimed at reaching a consensus. In the same session, they were asked to rank the wines by placing the sample codes on a line scale anchored at the left side 'low intensity' and right side 'high intensity'. In the second session, the ranking process was repeated with the descriptors previously established by each assessor. In this way, the wines of each variety, treatment, and aging time were evaluated in duplicate. Approximately $30-40 \mathrm{~mL}$ of wine was served, at $16-18{ }^{\circ} \mathrm{C}$, in clear wine tasting glasses (ISO 3591, 1977) labeled with three-digit random numbers. All assessments were conducted in individual tasting booths $\left(22-24{ }^{\circ} \mathrm{C}, 45-55 \% \mathrm{RH}\right)$. The number of assessors ranged from six to eight (50\% males and $50 \%$ females) aged $25-50$ years, all of whom were experts related to the wine industry. To 
participate in the evaluation, all panelists signed a consent form with the INTA. The study was approved by the INTA ethics committee.

\subsection{Data Analysis}

All chemical analyses were carried out in duplicate. Statistical analysis was assessed with Statgraphics Centurion XVI software (Statistical Graphics Corp., Warrenton, VA, USA, 2009) and $R$ (R Core, 2018). The results were tested for homogeneity of variance using Levene's test and analyzed by one-way (Experiment A) and two-way analysis of variance (Experiment B) and Tukey's honestly significant difference (HSD) test $(\alpha=0.05) . p<0.05$ was considered to be statistically significant. Flash profile data analyses were performed by multiple factor analysis (MFA) [28]. Confidence ellipses indicating 95\% confidence intervals were formed using the SensoMineR R package [29]. Descriptors mentioned by at least two assessors were used for the analysis.

\section{Results and Discussion}

\subsection{Experiment A: Application of Vine-Shoots during Winemaking}

The impact of vine-shoot chips during the vinification process of Malbec and Bonarda musts was different, revealing a possible varietal effect linked to the chemical composition of these matrices. It was found that Bonarda wines made applying vine-shoot chips toasted and untoasted show comparable levels of the different parameters evaluated. Meanwhile, in the case of Malbec, the addition of toasted material (CHT) caused a significant decrease in tannins, anthocyanins, and polymeric pigments and a modification of the qualitative and quantitative attributes of the color, mainly due to adsorption phenomena by the wood fragments.

\subsubsection{General Chemical Composition of Wines}

When evaluating the general analytical parameters of wines (Table 1), a differential impact of the vine-shoot chips was observed in both grape matrices, revealing a possible varietal effect. In the case of Bonarda wines, the addition of vine-shoots did not significantly modify the main enological parameters, in agreement with a similar previous study in Cencibel wines [15]. The mean values for all Bonarda wines were: alcohol, $14.94 \% v / v$; titratable acidity, $6.57 \mathrm{~g} / \mathrm{L} ; \mathrm{pH}, 3.56$; volatile acidity, $0.41 \mathrm{~g} / \mathrm{L}$; malic acid, $1.44 \mathrm{~g} / \mathrm{L}$. For the Malbec variety, the CHT and CHWT treatments generated a slight increase in alcohol content, a significant decrease in volatile acidity ( $20 \%$ and $29 \%$, respectively), and a notable stabilization of malic and tartaric acids (Table 1), indicating a possible modification of microbial metabolism when using vine-shoots. These results, although significant, cannot be attributed to a specific reason. According to previous studies about the characterization of vine-shoots for use as enological additives, the absence of ellagitannins was observed, unlike in oak wood $[11,13]$. Therefore, potentially, the release of procyanidins from vineshoots during winemaking could have a slight inhibitory effect on some microorganisms (mainly lactic acid bacteria), impacting the chemical composition of wines [30]. However, for the moment, it is only an assumption that needs to be verified by future, more specific studies.

\subsubsection{Global Phenolic Parameters and Wine Color}

In terms of global phenolics, Malbec wines responded differentially to the presence of vine-shoots (Figure 1). The application of toasted material (CHT) caused a decrease in the tannin and anthocyanin content in wines, compared to the control, due to adsorption phenomena and greater contact surface (for the same dose) compared to untoasted chips (CHWT) [31]. On the other hand, heat treatment during the toasting process generates the degradation of vine-shoot polyphenols, decreasing the rate of tannins available for diffusion during wine maceration [11,12]. Comparable levels of phenolic compounds were observed in wines with CHWT and the control (C), which would indicate a compensation 
effect between the extraction/transfer and precipitation/loss of these compounds by wood fragments.

Table 1. General analytical parameters of Malbec and Bonarda wines obtained applying vine-shoot chips during winemaking (Experiment A).

\begin{tabular}{|c|c|c|c|c|c|c|}
\hline Treatments & $\begin{array}{l}\text { Ethanol } \\
(\% v / v)\end{array}$ & $\mathrm{pH}$ & $\begin{array}{c}\text { Titratable } \\
\text { Acidity }(\mathrm{g} / \mathrm{L})\end{array}$ & $\begin{array}{c}\text { Volatile } \\
\text { Acidity }(\mathrm{g} / \mathrm{L})\end{array}$ & $\begin{array}{l}\text { Malic Acid } \\
\text { (g/L) }\end{array}$ & $\begin{array}{l}\text { Lactic Acid } \\
\text { (g/L) }\end{array}$ \\
\hline \multicolumn{7}{|l|}{ Malbec } \\
\hline C & $14.24^{*} \pm 0.04 \mathrm{a}$ & $3.74 \pm 0.04 \mathrm{a}$ & $6.19 \pm 0.09 a$ & $0.65 \pm 0.04 b$ & $0.90 \pm 0.15 a$ & $0.87 \pm 0.09 \mathrm{~b}$ \\
\hline CHWT & $14.45 \pm 0.03 b$ & $3.72 \pm 0.05 \mathrm{a}$ & $6.07 \pm 0.03 \mathrm{a}$ & $0.46 \pm 0.02 \mathrm{a}$ & $1.77 \pm 0.20 \mathrm{~b}$ & ND \\
\hline CHT & $14.40 \pm 0.01 \mathrm{~b}$ & $3.69 \pm 0.01 \mathrm{a}$ & $6.11 \pm 0.07 \mathrm{a}$ & $0.52 \pm 0.03 \mathrm{a}$ & $1.73 \pm 0.08 b$ & ND \\
\hline$p$-value & 0.0003 & 0.2754 & 0.1616 & 0.0005 & 0.0007 & $<0.0001$ \\
\hline \multicolumn{7}{|l|}{ Bonarda } \\
\hline C & $14.90 \pm 0.51 \mathrm{a}$ & $3.53 \pm 0.04 \mathrm{a}$ & $6.63 \pm 0.08 \mathrm{a}$ & $0.40 \pm 0.03 \mathrm{a}$ & $1.49 \pm 0.01 b$ & ND \\
\hline CHWT & $15.01 \pm 0.57 \mathrm{a}$ & $3.57 \pm 0.03 \mathrm{a}$ & $6.56 \pm 0.07 a$ & $0.41 \pm 0.03 \mathrm{a}$ & $1.41 \pm 0.03 \mathrm{a}$ & ND \\
\hline CHT & $14.92 \pm 0.42 \mathrm{a}$ & $3.58 \pm 0.03 \mathrm{a}$ & $6.50 \pm 0.11 \mathrm{a}$ & $0.41 \pm 0.03 \mathrm{a}$ & $1.43 \pm 0.05 \mathrm{ab}$ & ND \\
\hline$p$-value & 0.9601 & 0.2584 & 0.2835 & 0.6122 & 0.0499 & NA \\
\hline
\end{tabular}

${ }^{*}$ Mean $\pm \mathrm{SD}(n=3)$. Different letters in the same column for each variety indicate significant differences among treatments (Tukey HSD test, $p<0.05$ ). Significant $p$-values are shown in bold. C, control; CHWT, untoasted vine-shoot chips; CHT, toasted vine-shoot chips. ND, not detected. NA, not applicable
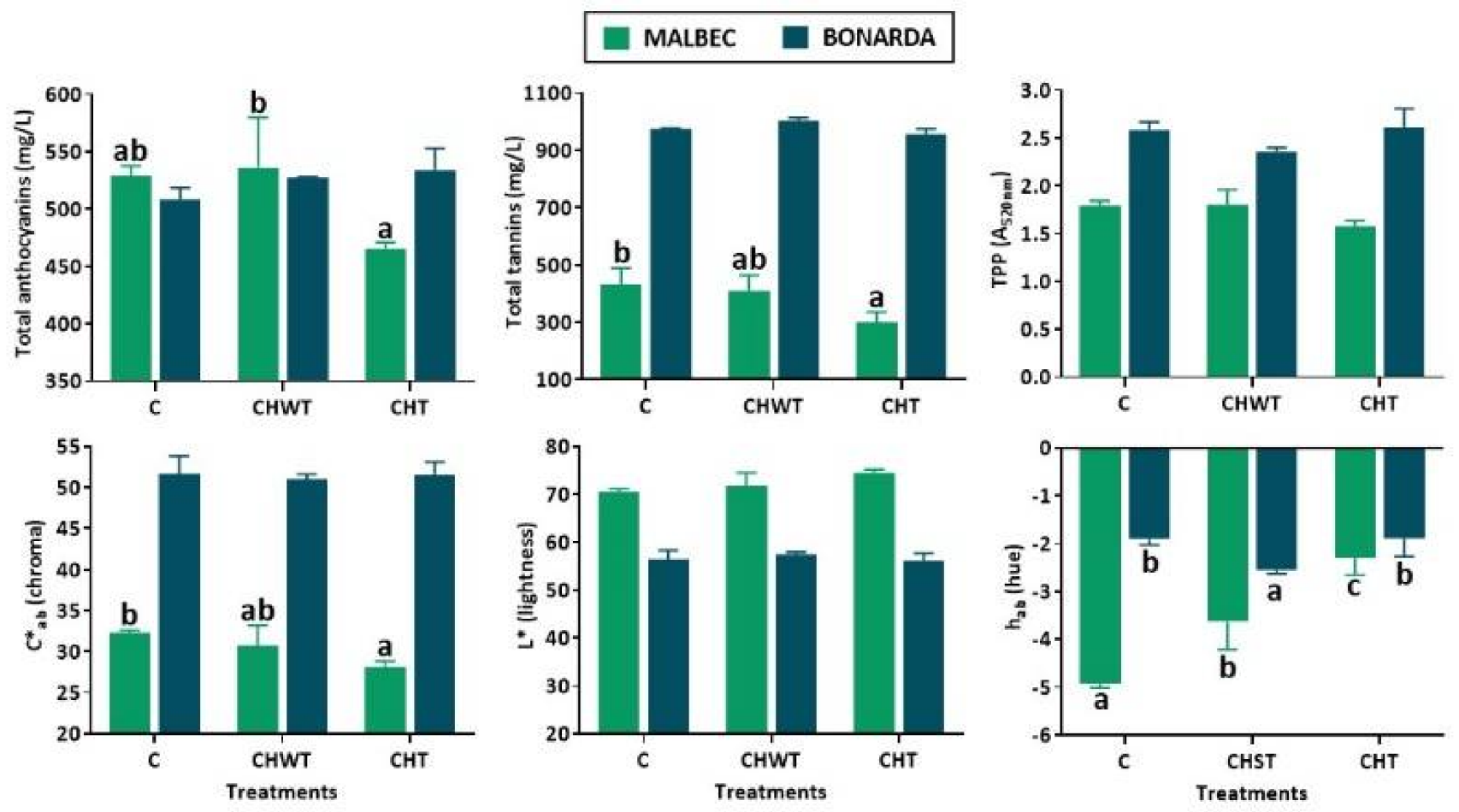

Figure 1. Global phenolic compositions and color parameters of Malbec and Bonarda wines, obtained by applying different vine-shoot treatments during winemaking. Different letters for each variety indicate significant differences between treatments (Tukey's HSD test, $p<0.05$ ). C, control; CHWT, untoasted vine-shoot chips; CHT, toasted vine-shoot chips; TPP, total polymeric pigments.

Polymeric pigments formed during winemaking provide stable color and positive mouthfeel properties. Their production is modulated by the relative molar amounts of anthocyanins and tannins [32]. Total polymeric pigments result from the summation of small polymeric pigments (SPP; including pyranoanthocyanins and flavanol-anthocyanin ethyl-bridged adducts that cannot precipitate proteins and are resistant to $\mathrm{SO}_{2}$ bleaching) and large polymeric pigments (LPP; covalent adducts between tannins and anthocyanins, 
of relatively high molecular weight, which can precipitate proteins and are resistant to $\mathrm{SO}_{2}$ bleaching) [33]. Accordingly, the total polymeric content (TPP) of Malbec wines made with CHT was lower, but not significant $(p=0.052)$, compared to wines from the $C$ and CHWT treatment groups (Figure 1). LPP formation followed the trend observed regarding the tannin and anthocyanin content in wines (data not shown).

For further understanding of the color composition of wines, samples were analyzed using CIELAB color space. Figure 1 shows the results for the quantitative $\left(\mathrm{C}^{*}{ }_{\mathrm{ab}}\right.$ and $\left.\mathrm{L}^{*}\right)$ and qualitative $\left(h_{\mathrm{ab}}\right)$ parameters in Malbec wines after fermentation-maceration with vineshoots. It was found that the color of $\mathrm{CHT}$ wines was less vivid, lighter (lowest $\mathrm{C}_{\mathrm{ab}}^{*}$ ), and showed a slight decrease of violet hues, given a marked decrease of $a^{*}$ and $b^{*}$ values. Conversely, the color of the control wines displayed a deeper color (higher $\mathrm{C}^{*}{ }_{\mathrm{ab}}$ ) and a shift towards a violet hue (decrease in $h_{a b}$ of $2.6^{\circ}$ ). Meanwhile, CHWT treatment showed intermediate behavior. The $\mathrm{L}^{*}$ value defines the lightness, the property according to which each color can be considered as equivalent to a member of the greyscale, between black and white, taking values within the range of $0-100$ [34]. As expected, a negative correlation was observed between $L^{*}$ and $C^{*}$ ab, but there were no significant differences for the $L^{*}$ parameter among the treatments studied. In summary, these results can be explained by the higher levels of phenolic compounds, especially anthocyanins and polymeric pigments, in the $\mathrm{C}$ and CHWT wines (Figure 1).

In order to evaluate the colorimetric difference amongst Malbec wines from different treatments, the total color difference $\left(\Delta \mathrm{E}_{\mathrm{ab}}^{*}\right)$ was determined. This parameter could be very important for the wine industry as it expresses the human eye's ability to discriminate between the colors of two wines. It is not possible to establish a concrete value for color discrimination because many factors condition this limit, such as viewing geometry, surroundings, and even the color region and the ability, visual capacity, and training of observers [35]. Some studies performed under specific conditions have established the visual discrimination threshold in wines between 3 and 5 CIELAB units [36,37], although these values must be considered in relative character. In the present study, the greatest color difference values $\left(\Delta \mathrm{E}_{\mathrm{ab}}^{*}\right)$ were found between the $\mathrm{C}$ and $\mathrm{CHT}$ wines (mean 6 CIELAB units) and the least differences between the CHWT and CHT wines (mean 4 units), although in all cases they were visually distinguished (Figure 2).

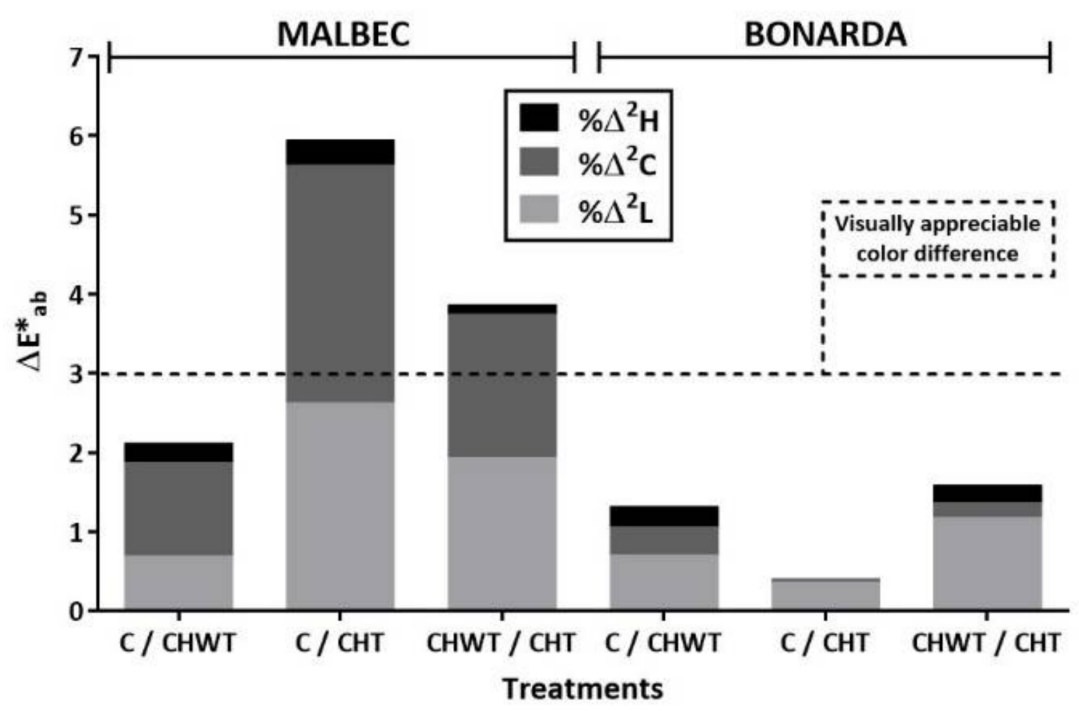

Figure 2. Color differences $\left(\Delta \mathrm{E}^{*} \mathrm{ab}\right)$, with the relative contributions of lightness, chroma, and hue $\left(\% \Delta^{2} \mathrm{~L}, \% \Delta^{2} \mathrm{C}, \% \Delta^{2} \mathrm{H}\right)$, for Malbec and Bonarda wines, obtained by applying different vine-shoot treatments during winemaking. $\mathrm{C}$, control; $\mathrm{CHWT}$, untoasted vine-shoot chips; $\mathrm{CHT}$, toasted vineshoot chips. 
In contrast, Bonarda wines obtained by different treatments showed a similar behavior (Figure 1), without changes in total tannins, anthocyanins, or polymeric pigments (SPP and LPP). This tendency coincides with results published by other authors when applying vineshoot chips during Cencibel winemaking [15]. A possible explanation for this differential effect compared to Malbec could be the high concentration of phenols (mean $2475 \mathrm{mg} / \mathrm{L}$ vs. $1606 \mathrm{mg} / \mathrm{L}$ ) and tannins (mean $978 \mathrm{mg} / \mathrm{L}$ vs. $381 \mathrm{mg} / \mathrm{L}$ ) in all Bonarda wines, which would minimize the impact of the vine-shoot wood on the wine phenolic matrix. In addition, the CIELAB parameters were also comparable, with only the CHWT treatment standing out for modifying the qualitative attribute $\left(h_{a b}\right)$, given a marked decrease of $b^{*}$ values and a color shift towards violet-bluish tones (lower $\left.\mathrm{h}_{\mathrm{ab}}\right)$. Likewise, the color differences $\left(\Delta \mathrm{E}_{\mathrm{ab}}^{*}\right)$ between wines from all the treatments applied presented values lower than 3 , indicating the impossibility of distinguishing them visually (Figure 2).

\subsubsection{Wine Anthocyanin Profile}

The identified and quantified compounds in the wine samples were grouped into non-acylated glucosides (five), acetyl-glucosides (five), cinnamoyl-glucosides (six), and low molecular anthocyanin-derived pigments (nine pyranoanthocyanins and two flavanolanthocyanin adducts). All identified compounds were detected in all of the wines studied. Figure S1 shows the results obtained in Malbec and Bonarda wines grouped by families. For Malbec samples, the simple glucosides represented the highest proportion of all anthocyanins $(65.1 \%)$, followed by acetylglucosides (14.8\%), cinnamoylglucosides $(9.8 \%)$, and pyranoanthocyanins $(8.5 \%)$, in accordance with previous results obtained by the research group for the same cultivar [35,38]. In the case of Bonarda, the proportions of the anthocyanin groups were $62.1 \%, 11.6 \%, 15.0 \%$, and $9.5 \%$, respectively, with some differences concerning published data on commercial wines [38].

In both matrices (Malbec and Bonarda wines), the anthocyanin composition evaluated by HPLC-DAD for all the treatments applied (Figure S1) showed a similar trend to the overall amount quantified by spectrophotometry (Figure 1). However, there were no statistically significant differences between them for the individual compounds identified and quantified $(p>0.05)$. This behavior could be explained by the fact that HPLC-DAD analysis only detects free anthocyanins, whereas spectrophotometric analysis includes other red pigments that may contribute to the observed differences [39].

\subsection{Experiment B: Application of Vine-Shoots during Wine Aging}

Vine-shoot addition, as an alternative technological strategy to oak chips, was studied for the aging of Malbec and Bonarda wines over four months. The experimental units resulting from the combination of the two study factors (aging time and vine-shoot treatment) were independent ( $375 \mathrm{~mL}$ bottles), which allowed the use of aging time as a fixed factor in a two-way ANOVA. The results indicated that the aging time and the vine-shoot treatment applied had a significant influence on the evolution of some chemical parameters. The interaction effects between the factors were more relevant for Malbec wines, indicating a possible synergism of them on $\mathrm{pH}$, anthocyanins, and color saturation (Figures 3 and 4).

\subsubsection{General Chemical Composition of Wines}

First, it is important to note that the Malbec and Bonarda wines used for this trial were adjusted to $0.6 \mathrm{mg} / \mathrm{L}$ of molecular $\mathrm{SO}_{2}$ to prevent malolactic fermentation. However, this process developed spontaneously and concluded around the first month of aging $(1 \mathrm{M})$, when malic acid consumption was observed in all experimental units $(<0.1 \mathrm{~g} / \mathrm{L})$. The results for the basic chemical parameters of wines analyzed by a two-way ANOVA, considering interactions between aging time (F1) and vine-shoot treatment (F2), are shown in Table 2 (Malbec) and Table 3 (Bonarda). 


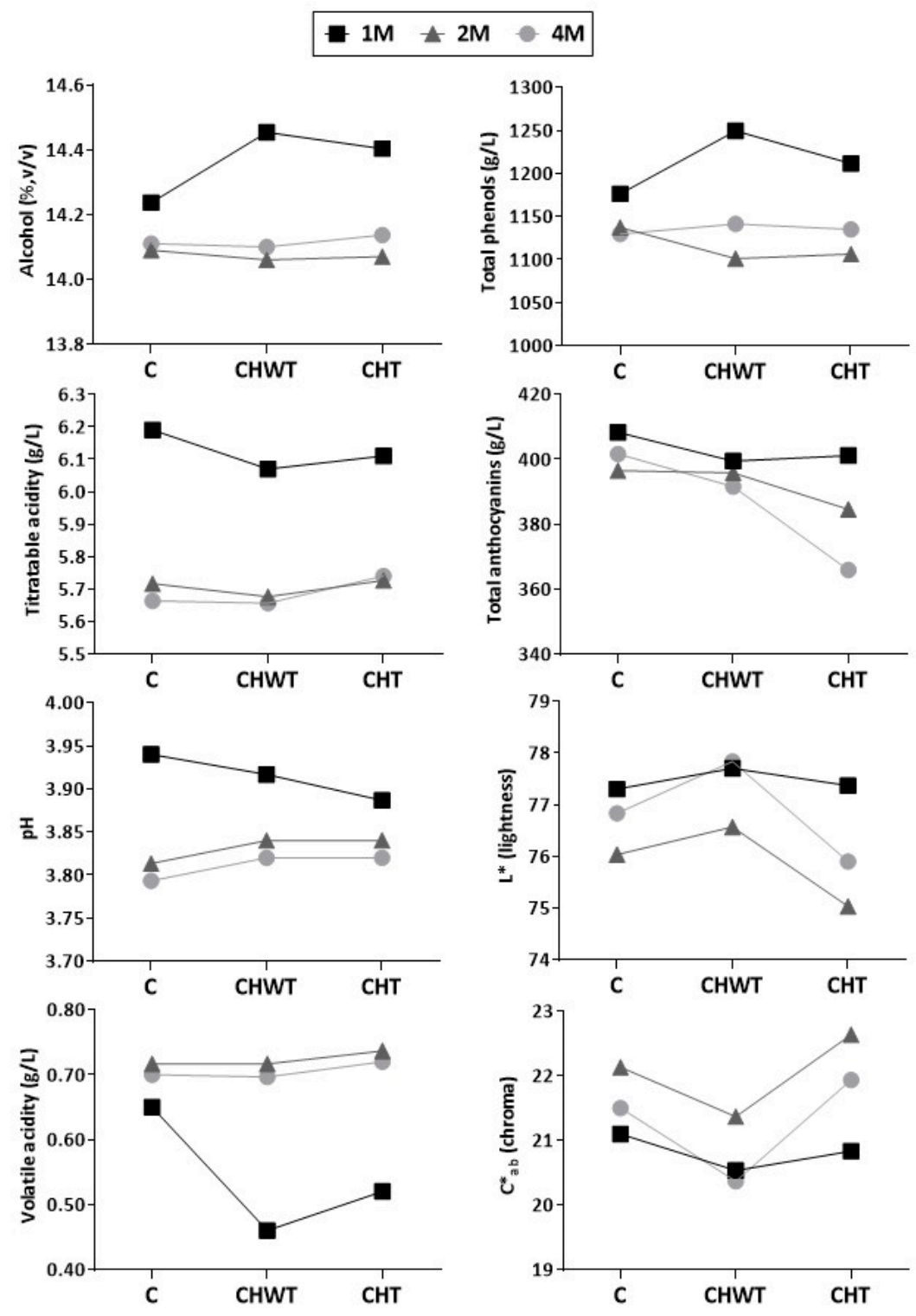

Figure 3. Interaction plots of aging time (F1) and vine-shoots treatments (F2) for analytical parameters in Malbec wines by two-way ANOVA. C, control; CHWT, untoasted vine-shoot chips; CHT, toasted vine-shoot chips; $1 \mathrm{M}, 30$ days; $2 \mathrm{M}, 60$ days; $4 \mathrm{M}, 120$ days.

두 $1 \mathrm{M} \pm 2 \mathrm{M}-4 \mathrm{M}$
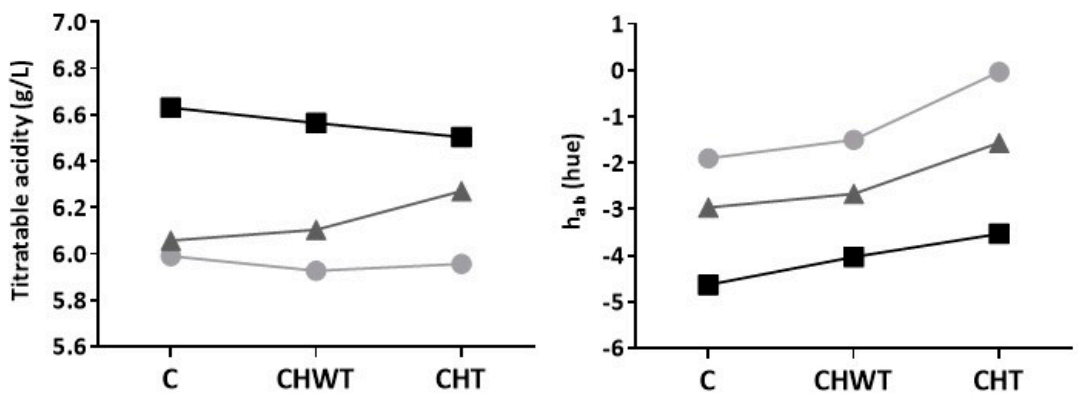

Figure 4. Interaction plots of aging time (F1) and vine-shoots treatments (F2) for analytical parameters in Bonarda wines by two-way ANOVA. C, control; CHWT, untoasted vine-shoot chips; CHT, toasted vine-shoot chips; $1 \mathrm{M}, 30$ days; $2 \mathrm{M}, 60$ days; $4 \mathrm{M}, 120$ days. 
Table 2. Basic chemical parameters of Malbec wines obtained applying vine-shoot chips during aging (Experiment B).

\begin{tabular}{|c|c|c|c|c|c|}
\hline $\begin{array}{l}\text { Aging } \\
\text { Time }\end{array}$ & $\begin{array}{l}\text { Vine-Shoot } \\
\text { Treatment }\end{array}$ & $\begin{array}{l}\text { Ethanol } \\
(\% v / v)\end{array}$ & $\mathrm{pH}$ & $\begin{array}{c}\text { Titratable } \\
\text { Acidity (g/L) }\end{array}$ & $\begin{array}{c}\text { Volatile } \\
\text { Acidity }(\mathrm{g} / \mathrm{L})\end{array}$ \\
\hline \multirow{3}{*}{$1 \mathrm{M}$} & C & $14.10 * \pm 0.04 \mathrm{a}$ & $3.78 \pm 0.04 \mathrm{a}$ & $6.07 \pm 0.08 \mathrm{a}$ & $0.66 \pm 0.04 b$ \\
\hline & CHWT & $14.31 \pm 0.03 b$ & $3.76 \pm 0.05 \mathrm{a}$ & $5.95 \pm 0.03 \mathrm{a}$ & $0.46 \pm 0.02 \mathrm{a}$ \\
\hline & $\mathrm{CHT}$ & $14.26 \pm 0.01 \mathrm{~b}$ & $3.73 \pm 0.01 \mathrm{a}$ & $5.99 \pm 0.07 \mathrm{a}$ & $0.53 \pm 0.03 \mathrm{a}$ \\
\hline \multicolumn{2}{|c|}{$p$-value } & 0.0003 & 0.2735 & 0.1602 & 0.0004 \\
\hline \multirow{3}{*}{$2 \mathrm{M}$} & C & $14.09 \pm 0.01 \mathrm{~b}$ & $3.81 \pm 0.01 \mathrm{a}$ & $5.72 \pm 0.01 b$ & $0.72 \pm 0.01 \mathrm{a}$ \\
\hline & CHWT & $14.06 \pm 0.00 \mathrm{a}$ & $3.84 \pm 0.01 b$ & $5.68 \pm 0.01 \mathrm{a}$ & $0.72 \pm 0.01 \mathrm{a}$ \\
\hline & $\mathrm{CHT}$ & $14.07 \pm 0.01 \mathrm{ab}$ & $3.84 \pm 0.01 \mathrm{~b}$ & $5.73 \pm 0.02 b$ & $0.74 \pm 0.01 \mathrm{a}$ \\
\hline \multicolumn{2}{|c|}{$p$-value } & 0.0110 & 0.0151 & 0.0041 & 0.0787 \\
\hline \multirow{3}{*}{$4 \mathrm{M}$} & C & $14.11 \pm 0.03 \mathrm{a}$ & $3.79 \pm 0.01 \mathrm{a}$ & $5.66 \pm 0.02 \mathrm{a}$ & $0.70 \pm 0.00 \mathrm{a}$ \\
\hline & CHWT & $14.10 \pm 0.02 \mathrm{a}$ & $3.82 \pm 0.00 b$ & $5.66 \pm 0.01 \mathrm{a}$ & $0.70 \pm 0.01 \mathrm{a}$ \\
\hline & CHT & $14.14 \pm 0.04 \mathrm{a}$ & $3.82 \pm 0.01 b$ & $5.74 \pm 0.01 \mathrm{~b}$ & $0.72 \pm 0.01 b$ \\
\hline \multicolumn{2}{|c|}{$p$-value } & 0.4315 & 0.0039 & 0.0003 & 0.0104 \\
\hline \multicolumn{6}{|c|}{ Two-way ANOVA } \\
\hline \multicolumn{2}{|c|}{ Aging time (F1) } & $<0.0001$ & $<0.0001$ & $<0.0001$ & $<0.0001$ \\
\hline \multicolumn{2}{|c|}{ Vine-shoot treatment (F2) } & 0.0002 & 0.5475 & 0.0081 & $<0.0001$ \\
\hline \multicolumn{2}{|c|}{ Interaction $(\mathrm{F} 1 \times \mathrm{F} 2)$} & $<0.0001$ & 0.0310 & 0.0367 & $<0.0001$ \\
\hline
\end{tabular}

${ }^{*}$ Mean $\pm \mathrm{SD}(n=3)$. Different letters in the same column for each aging time indicate significant differences among treatments (Tukey HSD test, $p<0.05)$. Significant $p$-values are shown in bold. C, control; CHWT, untoasted vine-shoot chips; CHT, toasted vine-shoot chips; $1 \mathrm{M}, 30$ days; $2 \mathrm{M}, 60$ days; $4 \mathrm{M}, 120$ days.

Table 3. Basic chemical parameters of Bonarda wines obtained applying vine-shoot chips during aging (Experiment B).

\begin{tabular}{|c|c|c|c|c|c|}
\hline $\begin{array}{l}\text { Aging } \\
\text { Time }\end{array}$ & $\begin{array}{l}\text { Vine-Shoot } \\
\text { Treatment }\end{array}$ & $\begin{array}{l}\text { Ethanol } \\
(\% v / v)\end{array}$ & $\mathrm{pH}$ & $\begin{array}{c}\text { Titratable } \\
\text { Acidity (g/L) }\end{array}$ & $\begin{array}{c}\text { Volatile } \\
\text { Acidity }(\mathrm{g} / \mathrm{L})\end{array}$ \\
\hline \multirow{3}{*}{$1 \mathrm{M}$} & $\mathrm{C}$ & $14.75 * \pm 0.50 \mathrm{a}$ & $3.57 \pm 0.05 \mathrm{a}$ & $6.50 \pm 0.08 \mathrm{a}$ & $0.40 \pm 0.03 \mathrm{a}$ \\
\hline & CHWT & $14.85 \pm 0.56 \mathrm{a}$ & $3.61 \pm 0.03 \mathrm{a}$ & $6.43 \pm 0.07 \mathrm{a}$ & $0.42 \pm 0.03 \mathrm{a}$ \\
\hline & $\mathrm{CHT}$ & $14.77 \pm 0.42 \mathrm{a}$ & $3.62 \pm 0.03 \mathrm{a}$ & $6.37 \pm 0.11 \mathrm{a}$ & $0.42 \pm 0.03 \mathrm{a}$ \\
\hline \multicolumn{2}{|c|}{$p$-value } & 0.9645 & 0.2506 & 0.2835 & 0.5637 \\
\hline \multirow{3}{*}{$2 \mathrm{M}$} & C & $14.64 \pm 0.02 \mathrm{a}$ & $3.67 \pm 0.01 \mathrm{a}$ & $6.06 \pm 0.04 \mathrm{a}$ & $0.57 \pm 0.01 \mathrm{a}$ \\
\hline & CHWT & $14.68 \pm 0.10 \mathrm{ab}$ & $3.69 \pm 0.02 \mathrm{ab}$ & $6.10 \pm 0.06 \mathrm{a}$ & $0.56 \pm 0.02 \mathrm{a}$ \\
\hline & $\mathrm{CHT}$ & $14.81 \pm 0.01 \mathrm{~b}$ & $3.71 \pm 0.01 \mathrm{~b}$ & $6.27 \pm 0.06 b$ & $0.59 \pm 0.01 \mathrm{a}$ \\
\hline \multicolumn{2}{|c|}{$p$-value } & 0.0341 & 0.0370 & 0.0063 & 0.0983 \\
\hline \multirow{3}{*}{$4 \mathrm{M}$} & C & $14.71 \pm 0.00 \mathrm{a}$ & $3.65 \pm 0.01 \mathrm{a}$ & $5.99 \pm 0.01 c$ & $0.57 \pm 0.01 \mathrm{a}$ \\
\hline & CHWT & $14.89 \pm 0.00 c$ & $3.71 \pm 0.01 \mathrm{~b}$ & $5.93 \pm 0.01 \mathrm{a}$ & $0.62 \pm 0.01 \mathrm{~b}$ \\
\hline & $\mathrm{CHT}$ & $14.87 \pm 0.01 \mathrm{~b}$ & $3.71 \pm 0.01 b$ & $5.96 \pm 0.01 b$ & $0.62 \pm 0.00 \mathrm{~b}$ \\
\hline \multicolumn{2}{|c|}{$p$-value } & $<0.0001$ & $<0.0001$ & 0.0001 & $<0.0001$ \\
\hline \multicolumn{6}{|c|}{ Two-way ANOVA } \\
\hline \multicolumn{2}{|c|}{ Aging time (F1) } & 0.6943 & $<0.0001$ & $<0.0001$ & $<0.0001$ \\
\hline \multicolumn{2}{|c|}{ Vine-shoot treatment $(\mathrm{F} 2)$} & 0.6481 & 0.0007 & 0.2861 & 0.0067 \\
\hline \multicolumn{2}{|c|}{ Interaction $(\mathrm{F} 1 \times \mathrm{F} 2)$} & 0.9650 & 0.7684 & 0.0016 & 0.1173 \\
\hline
\end{tabular}

${ }^{*}$ Mean $\pm \mathrm{SD}(n=3)$. Different letters in the same column for each aging time indicate significant differences among treatments (Tukey HSD test, $p<0.05$ ). Significant $p$-values are shown in bold. C, control; CHWT, untoasted vine-shoot chips; CHT, toasted vine-shoot chips; $1 \mathrm{M}, 30$ days; $2 \mathrm{M}, 60$ days; $4 \mathrm{M}, 120$ days.

For Malbec wines, a huge effect of the aging time factor $(93.3 \%$ and $97.4 \%)$ and a slight $\mathrm{F} 1 \times \mathrm{F} 2$ interaction effect $(5.6 \%$ and $0.9 \%)$ on $\mathrm{pH}$ and titratable acidity, respectively, were observed, revealing a small increase in $\mathrm{pH}$ during aging $(2 \mathrm{M}$ and $4 \mathrm{M})$ with vine-shoot chips (CHWT and CHT; Figure 3). This could be attributed to the extraction into the wine of potassium and calcium ions from the vine-shoots, enhancing their precipitation as tartrate salts, in agreement with data reported when applying other by-products of the vineyard (stems) during red winemaking [40]. Likewise, this process impacted titratable acidity, with 
a decrease during the aging time (between $1 \mathrm{M}$ and $4 \mathrm{M}$ ), especially with the CHT treatment (Table 2, Figure 3), which presented greater surface and relative mass for mineral release compared to the CHWT treatment. Meanwhile, in the case of volatile acidity, although the greatest impact was generated by the aging time factor $(82.1 \%)$, the F1 $\times \mathrm{F} 2$ interaction $(9.2 \%)$ and vine-shoot treatment $(8.7 \%)$ effects were more significant. The volatile acidity of the wines at time $1 \mathrm{M}$ showed a similar behavior to that observed at the end of alcoholic fermentation (Experiment A). The treatments with vine-shoots generated lower levels of volatile acidity than those of the control wines (Figure 3). These results are in agreement with previous studies conducted with oak chips in Aglianico wines and cannot be explained based on ethanol oxidation reactions by film yeasts or by a coupled autoxidation of wood phenols [41]. When analyzing the evolution during aging, the increase in volatile acidity for all treatments versus the previous time indicates an increase of oxidation reactions in the wines [31,41].

In the case of Bonarda wines, their $\mathrm{pH}$ values showed a similar trend to Malbec, with a significant effect of both individual factors (Table 3). However, there was no clear impact of the vine-shoots on titratable acidity, especially after two and four months of aging (Figure 4). Finally, volatile acidity was affected by the aging process and vine-shoot treatments, increasing gradually with time and showing the highest values in CHWT and $\mathrm{CHT}$ wines after four months.

\subsubsection{Global Phenolic Parameters and Wine Color}

Figure 5 shows the global phenolic parameters of Malbec wines obtained by applying vine-shoot treatments during aging. In particular, the phenolic composition was more affected by the aging time factor (higher level of significance, Table 4) on most of the parameters (total phenols, tannins, and polymeric pigments), while vine-shoot treatments more strongly influenced anthocyanin levels.
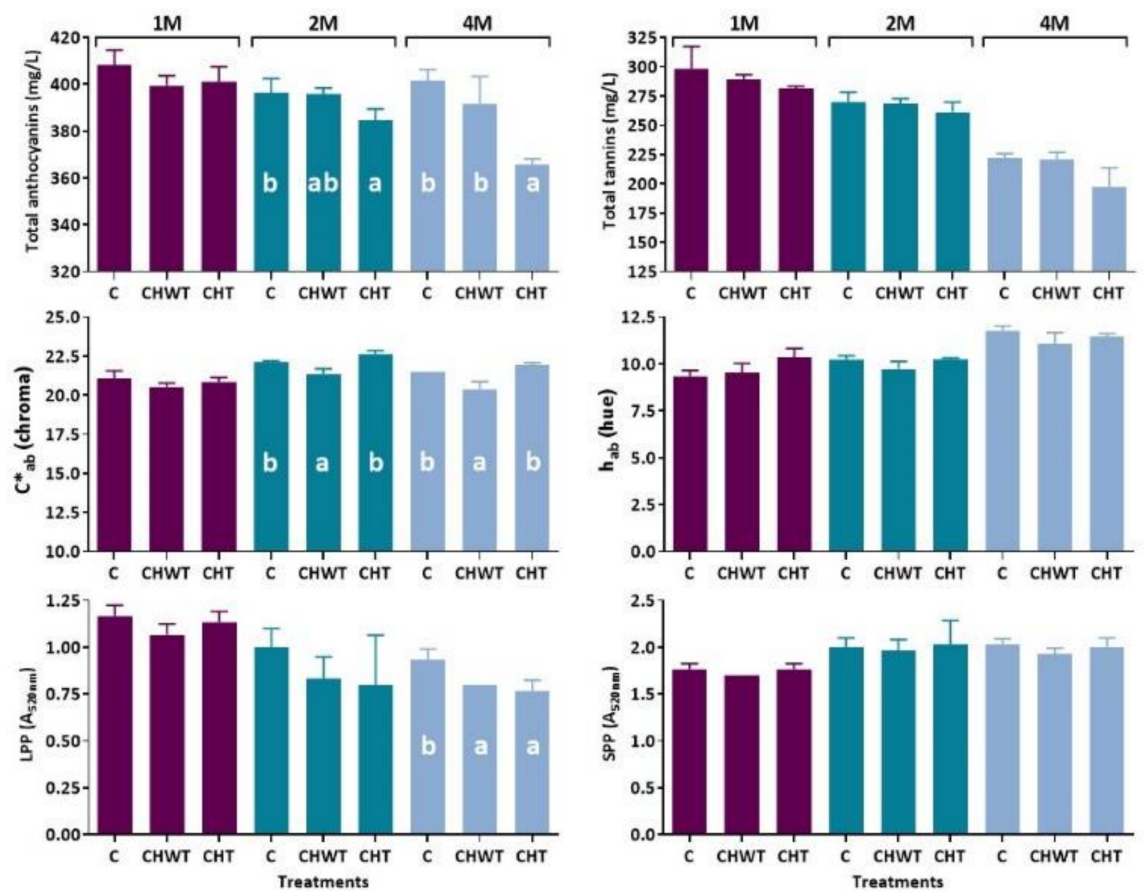

Figure 5. Global phenolic compositions and color parameters of Malbec wines obtained by applying vine-shoots during aging. Different letters for each aging time indicate significant differences between treatments (Tukey's HSD test, $p<0.05$ ). C, control; CHWT, untoasted vine-shoot chips; CHT, toasted vine-shoot chips; $1 \mathrm{M}, 30$ days; $2 \mathrm{M}, 60$ days; $4 \mathrm{M}, 120$ days; SPP, small polymeric pigments; LPP, large polymeric pigments. 
Table 4. Probability values (two-way ANOVA) for aging time (F1) and vine-shoot treatments (F2) to the global phenolic and color parameters in Malbec and Bonarda wines (Experiment B).

\begin{tabular}{|c|c|c|c|}
\hline \multirow{2}{*}{ Parameter } & \multicolumn{3}{|c|}{$p$-value ${ }^{a}$ for Factor } \\
\hline & F1 & F2 & $\mathbf{F} 1 \times F 2^{b}$ \\
\hline \multicolumn{4}{|l|}{ Malbec } \\
\hline Total phenols & $<0.0001$ & 0.3637 & 0.0225 \\
\hline Total tannins & $<0.0001$ & 0.0049 & 0.4915 \\
\hline Total anthocyanins & 0.0001 & $<0.0001$ & 0.0027 \\
\hline LPP & 0.0001 & 0.0285 & 0.7361 \\
\hline SPP & 0.0001 & 0.3571 & 0.9841 \\
\hline TPP & 0.1784 & 0.0001 & 0.0790 \\
\hline $\mathrm{L}^{*}$ & $<0.0001$ & $<0.0001$ & 0.0047 \\
\hline $\mathrm{C}_{\mathrm{ab}}^{*}$ & $<0.0001$ & $<0.0001$ & 0.0175 \\
\hline$h_{a b}$ & $<0.0001$ & 0.0121 & 0.0612 \\
\hline \multicolumn{4}{|l|}{ Bonarda } \\
\hline Total phenols & $<0.0001$ & 0.0001 & 0.1165 \\
\hline Total tannins & $<0.0001$ & 0.0019 & 0.9012 \\
\hline Total anthocyanins & $<0.0001$ & 0.0018 & 0.3873 \\
\hline LPP & 0.5928 & 0.0011 & 0.9884 \\
\hline SPP & $<0.0001$ & 0.0047 & 0.2178 \\
\hline TPP & $<0.0001$ & $<0.0001$ & 0.8834 \\
\hline $\mathrm{L}^{*}$ & 0.0001 & 0.0002 & 0.3416 \\
\hline $\mathrm{C}_{\mathrm{ab}}^{*}$ & 0.0001 & $<0.0001$ & 0.2540 \\
\hline $\mathrm{h}_{\mathrm{ab}}$ & $<0.0001$ & $<0.0001$ & 0.0389 \\
\hline
\end{tabular}

${ }^{\mathrm{a}}$ Considered to be significant when $p<0.05$ (shown in bold). ${ }^{\mathrm{b}}$ Interaction effect between aging time (F1) and vine-shoot treatments (F2).

A two-factor ANOVA showed significant F1 $\times$ F2 interaction of total phenols and anthocyanins (Table 4). This suggests that the effect of vine-shoot treatments applied (F2) did depend upon the aging time (F1). In other words, the vine-shoots (CHWT and CHT) in wines at 30 days of aging $(1 \mathrm{M})$ produced contrasting effects on phenols (increasing higher than control wines), compared to the behavior at $2 \mathrm{M}$ and $4 \mathrm{M}$ (Figure 3). Likewise, the application of CHT at 1M had a similar impact on wine anthocyanins to CHWT, while it produced a significant decrease of these compounds at a longer aging time. After the first month of aging $(1 \mathrm{M})$, the tannins and anthocyanins in wines were higher than at a longer aging time (2M and $4 \mathrm{M})$, while the small polymeric pigments (SPP) showed an opposite trend (Figure 5). These continuous decreases throughout aging could be explained by different reactions such as oxidation, hydrolysis, condensation, or polymerization, as reported by other authors $[18,42,43]$. At the same time, vine-shoot chips, especially toasted (CHT), might adsorb these compounds, mainly anthocyanins, provoking a slow decrease in their concentration throughout the aging process. These results are consistent with previous studies employing vine-shoot wood [15] and oak wood $[18,44]$.

Considering the contribution of different polymeric pigments to the total color of wines, the vine-shoot addition only affected the large polymeric pigment (LPP) accumulation toward the end of aging $(4 \mathrm{M})$, in agreement with the anthocyanin and tannin levels at that point (Figure 5, Table 4). This finding could be related to the adsorption and precipitation of pigments by vine-shoot chips (CHWT and CHT) over time [42]. In addition, the small polymeric pigments (SPP) contained anthocyanin-derived compounds originating from different mechanisms (direct reaction, cross-linking reaction, cycloaddition), which progressively increased during aging (Table 4), without significant differences among vine-shoot treatments. This trend has been widely reported in the literature, including in a previous study by a research group investigating Malbec wine aging [43].

When CIELAB parameters were analyzed, a greater impact of the aging time $(52.8 \%$ and $57.7 \%)$ and vine-shoot treatment $(41.8 \%$ and $36.5 \%)$ factors than of the F1 $\times$ F2 interaction effect $(5.4 \%$ and $5.8 \%)$ on chroma $\left(\mathrm{C}^{*} \mathrm{ab}\right)$ and lightness $\left(\mathrm{L}^{*}\right)$, respectively, was observed (Table 4). Regardless of vine-shoot treatment, the color saturation $\left(\mathrm{C}_{\mathrm{ab}}^{*}\right)$ of wines showed a 
significant increase only until the second month of the aging period and then experienced a gradual reduction. Conversely, the lightness $\left(L^{*}\right.$, not shown) and hue $\left(h_{a b}\right)$ displayed gradual increases, especially from 60 days $(2 \mathrm{M})$ onwards (Figure 5$)$. Similar behavior was observed in other studies with wines under different wood aging conditions [45-47]. The decline of violet hues $\left(>h_{a b}\right)$ and the shift to red-orange hues in all the wines during aging could be related to the decrease of anthocyanins and the increase of SPP (Figure 5), related to orange tones [48]. Assessing the impact of vine-shoots on the final color of Malbec wines, an opposite trend was observed to that found during vinification (Figure 1). The color of CHWT wines throughout the entire aging process was slightly lighter (lowest $\mathrm{C}^{*}{ }_{\mathrm{ab}}$ ), with a small but not significant increase of violet hues $\left(<h_{a b}\right)$ compared to $C$ and CHT wines (Figures 4 and 5).

Finally, the total color difference $\left(\Delta \mathrm{E}_{\mathrm{ab}}^{*}\right)$ between Malbec wines during aging was also evaluated and compared according to the aging time and the vine-shoot chips applied. For some authors, a $\Delta \mathrm{E}^{*}$ ab between 3 and 5 CIELAB units could establish, under specific conditions, the visual discrimination threshold among two samples [36,37]. The values obtained in this study for all wine comparisons were lower than 3 , revealing the absence of differences appreciable by an average observer.
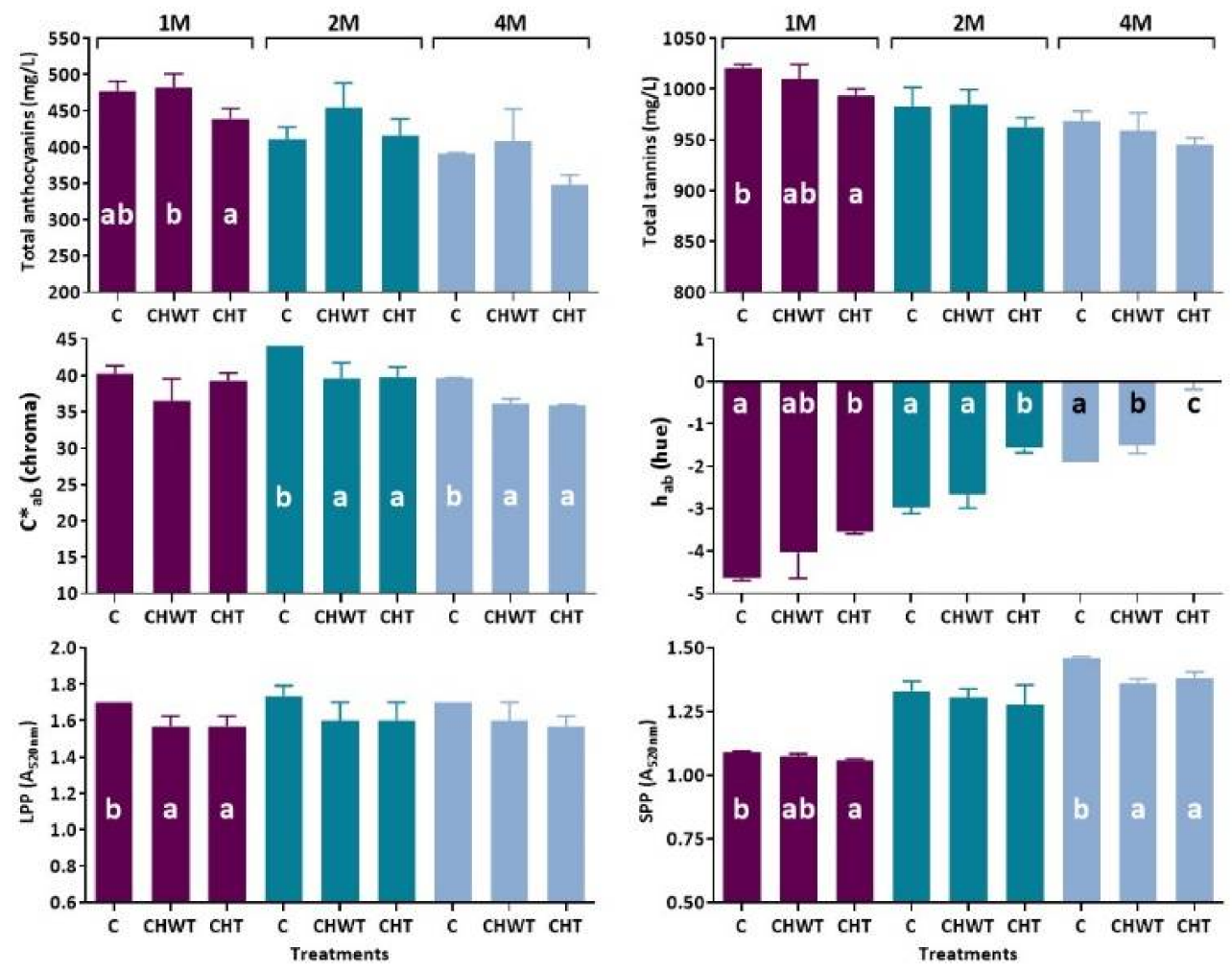

Figure 6. Global phenolic compositions and color parameters of Bonarda wines obtained by applying vine-shoots during aging. Different letters for each aging time indicate significant differences between treatments (Tukey's HSD test, $p<0.05$ ). C, control; CHWT, untoasted vine-shoot chips; CHT, toasted vine-shoot chips; $1 \mathrm{M}, 30$ days; $2 \mathrm{M}, 60$ days; $4 \mathrm{M}, 120$ days; SPP, small polymeric pigments; LPP, large polymeric pigments.

Figure 6 shows the phenolic and color parameters of Bonarda wines obtained by applying vine-shoot treatments during aging. Data obtained from the two-way ANOVA model show only a significant interaction F1 $\times$ F2 effect $(p<0.05)$ on the qualitative attribute of wine color $\left(\mathrm{h}_{\mathrm{ab}}\right)$, and a strong impact of both individual factors on the rest of the parameters (Table 4$)$. A continuous decrease in violet hues $\left(>h_{a b}\right)$ and a displacement towards red-orange tones was observed in the wines during aging, mainly with $\mathrm{CHT}$ at $2 \mathrm{M}$ and $4 \mathrm{M}$ (Figures 4-6). Likewise, the anthocyanin and tannin levels in the wines of 
all treatments followed a similar pattern to that observed in Malbec (Figure 5), characterized by a continuous decrease toward the end of the study $(4 \mathrm{M})$. Also, aging in contact with vine-shoot toasted chips (CHT) accentuated this trend, probably due to oxidation or condensation reactions between anthocyanins, tannins, and certain wood molecules, generating large, insoluble, and precipitable polymers [18]. This behavior led to a lower rate of polymeric pigments (LPP and SPP), throughout the study, when vine-shoot wood was applied (Figure 6). However, regardless of the vine-shoots, a gradual accumulation of SPP was observed during aging, in agreement with that obtained in Malbec wines (Figure 5).

The evaluation of color parameters in Bonarda wines revealed a significant impact $(p<0.001)$ of aging time and vine-shoot addition, in both quantitative $\left(\mathrm{L}^{*}, \mathrm{a}^{*}, \mathrm{C}^{*} \mathrm{ab}\right)$ and qualitative $\left(b^{*}, h_{a b}\right)$ parameters (Table 4$)$. As expected, the color evolution over time was in agreement with the development of the wine pigments. As aging progressed, the color saturation $\left(\mathrm{C}^{*}{ }_{\mathrm{ab}}\right)$ of wines, especially with vine-shoots (CHWT and CHT), gradually decreased, while the hue $\left(h_{a b}\right)$ shifted from violet-blue to orange-red tones (Figure 6). Differential Tristimulus Colorimetry was also applied to objectively assess the visual color discrimination between samples (Figure 7). Except for the first month of aging, during the remainder of the study, higher color difference values $\left(\Delta \mathrm{E}_{\mathrm{ab}}^{*}\right)$ were found between the control wines $(\mathrm{C})$ and vine-shoot-treated samples (CHWT, mean 5.5 CIELAB units; CHT, mean 5.2 units), and lower one between the CHWT and CHT wines (mean 1.1 units). Therefore, the application of vine-shoot chips (toasted and untoasted) significantly reduced the wine color, mainly in quantitative terms $\left(\% \Delta^{2} \mathrm{C}_{\mathrm{ab}}^{*}>55\right)$. Analyzing the influence of aging time, the greatest color difference (mean 6 units) was observed at two months $(2 \mathrm{M})$ in the wines obtained from all treatments. Following the same trend indicated above, the aging time studied also impacted the wine color in mainly quantitative terms $\left(\% \Delta^{2} \mathrm{C}_{\mathrm{ab}}^{*}>45\right.$; Figure 7$)$.

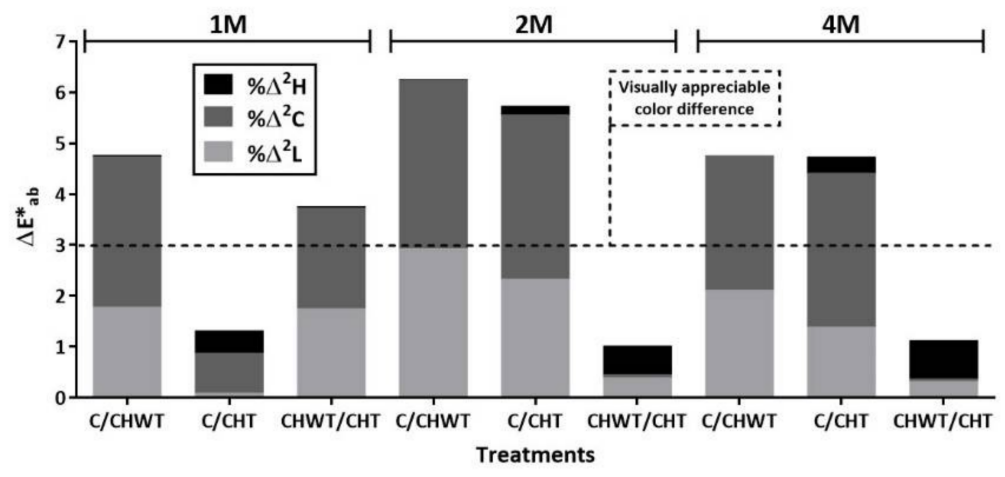

Figure 7. Color differences $\left(\Delta \mathrm{E}_{\mathrm{ab}}^{*}\right)$ with the relative contributions of lightness, chroma, and hue $\left(\% \Delta^{2} \mathrm{~L}, \% \Delta^{2} \mathrm{C}, \% \Delta^{2} \mathrm{H}\right)$ for Bonarda wines, obtained by applying different vine-shoot treatments during aging. $\mathrm{C}$, control; CHWT, untoasted vine-shoot chips; $\mathrm{CHT}$, toasted vine-shoot chips; $1 \mathrm{M}, 30$ days; $2 \mathrm{M}, 60$ days; $4 \mathrm{M}, 120$ days.

\subsubsection{Wine Anthocyanin Profile}

Figures S2 and S3 show the individual anthocyanins of Malbec and Bonarda wines obtained by applying vine-shoot treatments during aging, following the same categorization by families as described in Experiment A. In detail, the compounds identified and quantified in all wine samples are summarized in Tables S1 and S2. For both varieties, all the compounds were strongly affected $(p<0.001)$ by the aging factor $(\mathrm{F} 1)$, characterized by a continuous decrease throughout the time of monoglucosides and acetylated and cinnamoylated derivatives. These results are in agreement with previous reports that evaluated different wine varieties and aging woods $[15,17,18,49,50]$. Concerning vine-shoot treatments (F2), a significant influence was observed on glucosylated and cinnamoylated derivatives in Malbec wines (Figure S2), while for Bonarda, this factor affected all the com- 
pounds (Figure S3). Consequently, the anthocyanin composition evaluated by HPLC-DAD for all the treatments applied in both matrices (Malbec and Bonarda) showed a similar trend to the overall amount quantified by spectrophotometry and the color evolution over time (Figures 5 and 6).

Pyranoanthocyanins are anthocyanin-derived pigments formed by the reaction of monomeric anthocyanins with acetaldehyde, acetoacetic acid, pyruvic acid, and other carbonyl compounds $[26,51]$. These compounds are of interest for winemakers because they have high stability during the aging of red wines, are more resistant to elevated $\mathrm{pH}$ values and bisulfite bleaching than anthocyanins, and express more color than other pigments at the typical pH of wine [51]. Meanwhile, ethylene-bridged flavanol-anthocyanin adducts often disappear during wine aging, maybe due to the reported instability of the ethylidene linkage [52]. In the present study, the decline of derived pigments during the aging period (Figures S2 and S3) did not support the greater proportion of small polymeric pigments (SPP) obtained by spectrophotometry (Figures 5 and 6). This inconsistency could be attributed to other phenolic and non-phenolic compounds (not determined in the present study), which may vary in their composition and content with the treatments applied and contribute to the SPP quantitation.

\subsubsection{Sensory Analysis}

Flash profile was used to explore the effect of vine-shoot chips' addition on the sensory profile of wines during aging (Experiment B). To analyze the FP data, multiple factor analysis was used [28]. The MFA biplot and confidence ellipses were constructed with 95\% certainty according to Cadoret and Husson [53], which provides significance testing. The frequency of the use of descriptors was used to characterize different treatments. Tables S3 and S4 show the contributions, in percentages, of dimensions 1 and 2 of the top 20 descriptors for Malbec and Bonarda wines at each aging time.

Figure 8 shows the sensory profile of Malbec wines for the different aging times. At the three time points, the total variability was explained mainly with the first two dimensions of the MFA. There were no overlaps among the treatments at any of the three times at which the FP was performed, indicating these wines were significantly different from each other. At $1 \mathrm{M}$ (Figure 8A1,A2), the scores of the MFA suggest that wines aging with vine-shoot chips (CHWT and CHT) were more intense in aroma. The judges also cited descriptors such as fullness, wood, coffee, and toasted. The wood descriptor was more frequently related to CHT wines, whereas the herbaceous descriptor was related to CHWT wines. This attribute only appeared at this time and was absent in the remaining aging times. Control wines were perceived as fruity, bitter, and also acidic, possibly due to the higher level of volatile acidity since there were no differences in $\mathrm{pH}$ or titratable acidity compared with the other treatments (Table 2). The sensory profile of the wines remained fairly constant after 2M (Figure 8B1,B2). Despite this, new descriptors appeared for the vine-shoot chip-aged wines. The new attributes were chocolate, smoke, spicy, dark fruit, and rubber. At $4 \mathrm{M}$ (Figure 8C1,C2), descriptors associated with woods like smoke, chocolate, spicy, toasted, and more astringency characterized the CHT wines, while CHWT wines were perceived as having more of a jam aroma. As in the previous aging stages, control wines were still associated with fruit.

For Bonarda wines, the variability of the sensory data was also explained by the first two dimensions of the MFA. Similar descriptors to Malbec were observed throughout the aging period, showing clear differences between treatments. At 1M (Figure 9A1,A2), the control wines were perceived as fruity and jam-like. As in Malbec wines, treatments with the addition of vine-shoot chips (CHWT, CHT) were related to descriptors such as wood, smoke, toasted, chocolate, fullness, and astringency. These wines were clearly perceived with more color intensity in contrast to CIELAB parameters and $\Delta \mathrm{E}^{*}$ ab (Figures 6 and 7 ). After two months of aging (Figure 9B1,B2), the coffee, spicy, and bitter attributes appeared in CHT wines, while CHWT samples were characterized by the rubber descriptor and more astringency. Towards the end of the study (Figure $9 \mathrm{C} 1, \mathrm{C} 2$ ), the control wines were 
perceived as fruity, containing dark fruits, and jam-like, while the behavior of wines treated with vine-shoots chips was similar to that found previously. Only the presence of the floral attribute in CHWT wines is highlighted. In general, the sensory profile of Malbec and Bonarda wines, mainly in the mouth and color attributes, did not correlate with the phenolic chemical data (Figures 5 and 6). However, the absence of information on the volatile composition and polysaccharides of these wines prevents us from making a complete interpretation of the chemical and sensory impacts of the treatments applied.
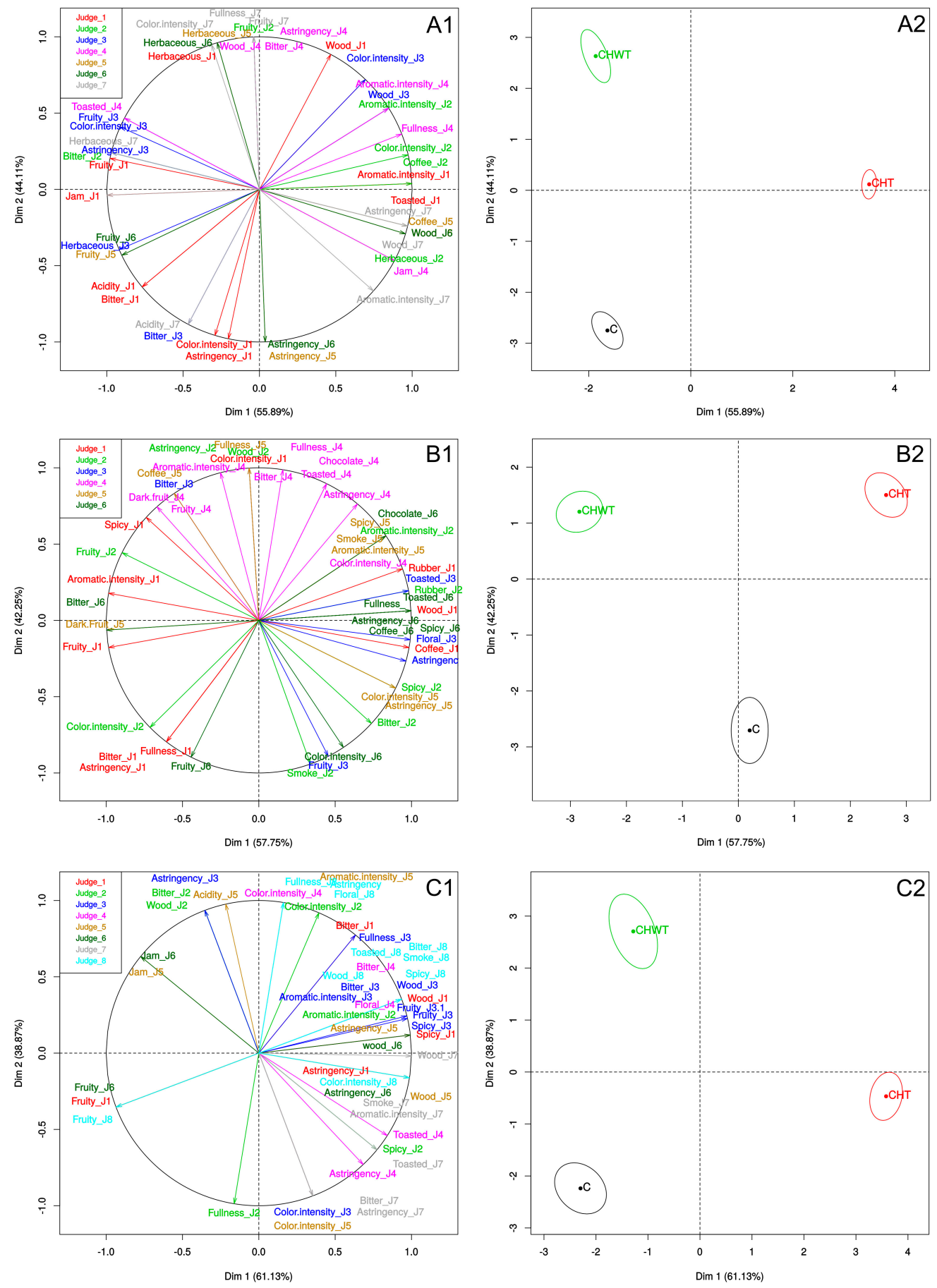

Figure 8. Multiple factor analysis (MFA) of Malbec wines (Experiment B). (1) Circle plot of MFA correlations among judges; (2) MFA consensus plot showing wine scores. Confidence ellipses indicate 95\% confidence intervals. (A) 1M; (B) 2M; (C) 4M. C, control; CHWT, untoasted vine-shoot chips; $\mathrm{CHT}$, toasted vine-shoot chips; $1 \mathrm{M}, 30$ days; $2 \mathrm{M}, 60$ days; $4 \mathrm{M}, 120$ days. 

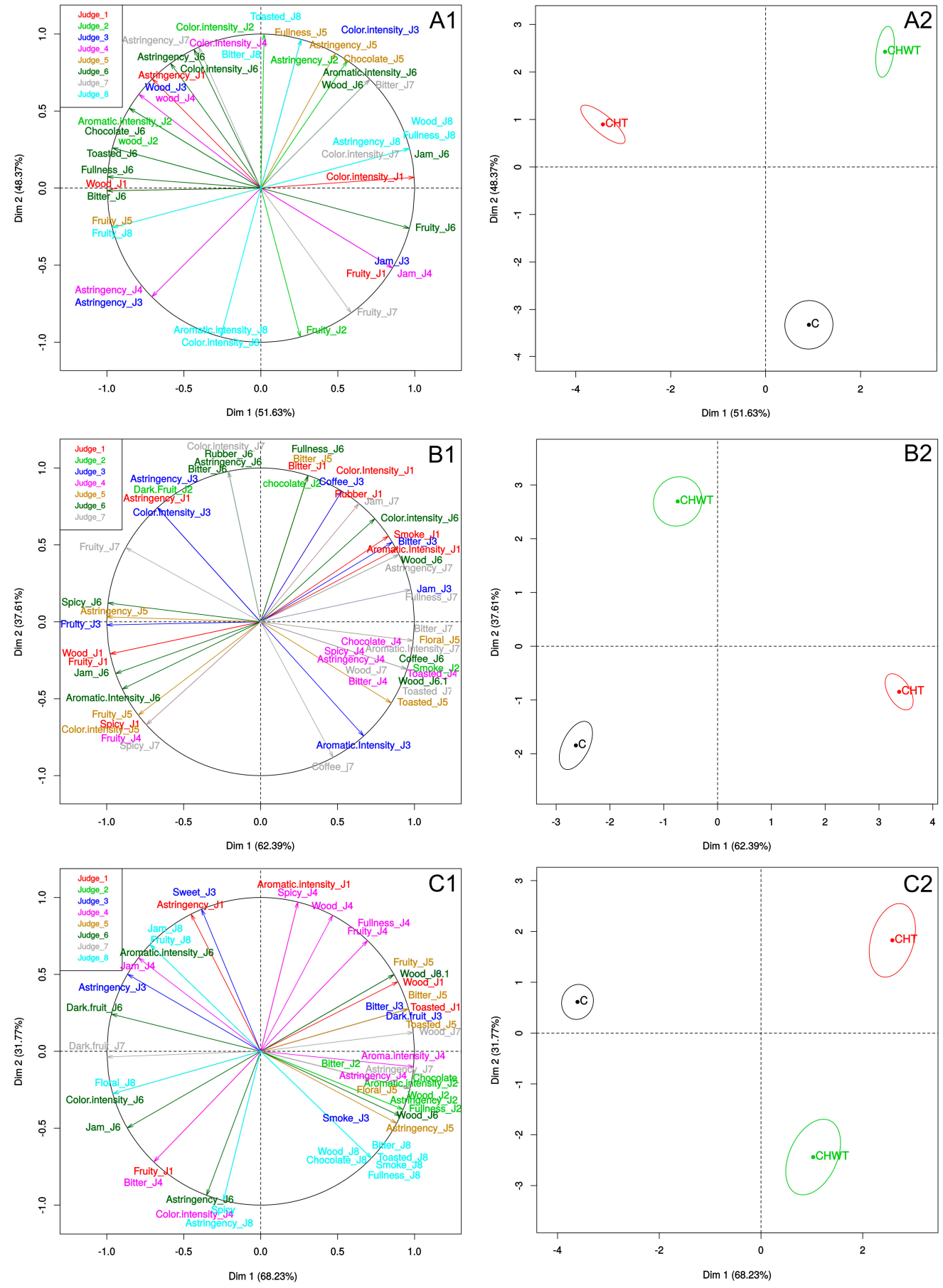

Figure 9. Multiple factor analysis (MFA) of Bonarda wines (Experiment B). (1) Circle plot of MFA correlations among judges; (2) MFA consensus plot showing wine scores. Confidence ellipses indicate 95\% confidence intervals. (A) 1M; (B) 2M; (C) 4M. C, control; CHWT, untoasted vine-shoot chips; CHT, toasted vine-shoot chips; $1 \mathrm{M}, 30$ days; $2 \mathrm{M}, 60$ days; $4 \mathrm{M}, 120$ days.

\section{Conclusions}

The present work proposes a technological alternative, consisting of the use of a by-product of the grapevine, the vine-shoots, as a potential enological additive for Malbec and Bonarda varieties, producing wines of good sensory quality. Vine-shoots positively influenced the wines' complexity in terms of aromatic attributes and mouthfeel. Further studies on this topic are needed to evaluate other experimental conditions such as the doses to be applied, the varietal origin of the wood material, and the contact time with white and red wines. Moreover, it is important to complement these results with data 
about the effects on the volatile chemical composition and polysaccharide matrix for a better interpretation of the organoleptic impact on the wines. Nonetheless, the proposed technology could present a simple and economical tool for red wine production with high chemical and organoleptic quality, capable of competing and satisfying market needs.

Supplementary Materials: The following are available online at https:/ /www.mdpi.com/article/10 .3390/beverages7030051/s1. Figure S1: Anthocyanins and derived pigments of Malbec and Bonarda wines obtained by applying different vine-shoot treatments during winemaking. C, control; CHWT, untoasted vine-shoot chips; CHT, toasted vine-shoot chips; ANT-derived pigments, pyranoanthocyanins + flavanol-anthocyanin adducts. Figure S2: Anthocyanins and derived pigments of Malbec wines obtained by applying different vine-shoot treatments during aging. Significant $p$-values by two-way ANOVA (Tukey's HSD test, $p<0.05$ ) are shown in bold. F1, aging time; F2, vine-shoot treatments; C, control; $\mathrm{CHWT}$, untoasted vine-shoot chips; $\mathrm{CHT}$, toasted vine-shoot chips; $1 \mathrm{M}, 30$ days; 2M, 60 days; 4M, 120 days; F-A, flavanol-anthocyanin adducts. Figure S3: Anthocyanins and derived pigments of Bonarda wines obtained by applying different vine-shoot treatments during aging. Significant $p$-values by two-way ANOVA (Tukey's HSD test, $p<0.05$ ) are shown in bold. F1, aging time; F2, vine-shoot treatments; C, control; $\mathrm{CHWT}$, untoasted vine-shoot chips; $\mathrm{CHT}$, toasted vineshoot chips; $1 \mathrm{M}, 30$ days; $2 \mathrm{M}, 60$ days; $4 \mathrm{M}, 120$ days; F-A, flavanol-anthocyanin adducts. Table S1: Concentration $(\mathrm{mg} / \mathrm{L}$ ) of individual anthocyanins of Malbec wines obtained by applying vine-shoot chips during aging (Experiment B). Table S2: Concentration ( $\mathrm{mg} / \mathrm{L}$ ) of individual anthocyanins of Bonarda wines obtained by applying vine-shoot chips during aging (Experiment B). Table S3: Relative contributions (\%) of top 20 Malbec descriptors to the first and second MFA axes. Table S4: Relative contributions (\%) of top 20 Bonarda descriptors to the first and second MFA axes.

Author Contributions: Conceptualization, M.F.; methodology, M.F. and S.S.; software, A.C.; validation, M.A., V.J., and J.P.; formal analysis, M.F. and M.A.; investigation, M.F., S.S., and D.G.Q.; data curation, J.L.S. and D.G.Q.; writing-original draft preparation, M.F.; writing — review and editing, M.F., A.C., and J.P.; visualization, M.F. and S.S.; supervision, V.J.; project administration, M.F.; funding acquisition, M.F. All authors have read and agreed to the published version of the manuscript.

Funding: This work was funded by UMaza Research Project (2019-2022) and INTA Project 1.6.2.7.PD.I153 (2019-2022).

Informed Consent Statement: Informed consent was obtained from all subjects involved in the study. Data Availability Statement: Not applicable.

Acknowledgments: The authors are grateful to the members of the sensory panel (INTA), and especially Esteban Bolcato, for their technical assistance.

Conflicts of Interest: The authors declare no conflict of interest.

\section{References}

1. Velasco, M.C.V.; de Cerio, M.C.D.; Dietrich, T.; Rodríguez, E. Subproductos hortofrutícolas para una bioeconomía circular. Mediterráneo Econ. 2018, 31, 251-272.

2. Sánchez-Gómez, R.; Zalacain, A.; Alonso, G.L.; Salinas, M.R. Vine-shoot waste aqueous extracts for re-use in agriculture obtained by different extraction techniques: Phenolic, volatile, and mineral compounds. J. Agric. Food Chem. 2014, 62, 10861-10872. [CrossRef] [PubMed]

3. Peralbo-Molina, T.; Luque de Castro, M.D. Potential of residues from the Mediterranean agriculture and agrifood industry. Trends Food Sci. Technol. 2013, 32, 16-24. [CrossRef]

4. Sánchez-Gómez, R.; Zalacain, A.; Pardo, F.; Alonso, G.L.; Salinas, M.R. An innovative use of vine-shoots residues and their "feedback" effect on wine quality. Innov. Food Sci. Emerg. Technol. 2016, 37, 18-26. [CrossRef]

5. Sánchez-Gómez, R.; Zalacain, A.; Pardo, F.; Alonso, G.L.; Salinas, M.R. Moscatel vine-shoot extracts as a grapevine biostimulant to enhance wine quality. Food Res. Int. 2017, 98, 40-49. [CrossRef] [PubMed]

6. Sánchez-Gómez, R.; Pérez-Álvarez, E.P.; Salinas, R.; Gonzalo-Diago, A.; Zalacain, A.; Garde-Cerdan, T. Effect of vine-shoot and oak extract foliar grapevine applications on oenological parameters, phenolic acids and glutathione content of white musts and wines. OENO One 2020, 54, 145-156. [CrossRef]

7. Sánchez-Gómez, R.; Sánchez-Vioque, R.; Santana-Méridas, O.; Martín-Bejerano, M.; Alonso, G.L.; Salinas, M.R.; Zalacain, A. A potential use of vine-shoot wastes: The antioxidant, antifeedant and phytotoxic activities of their aqueous extracts. Ind. Crops Prod. 2017, 97, 120-127. [CrossRef] 
8. Delgado de la Torre, M.P.; Priego-Capote, F.; Luque de Castro, M.D. Comparative profiling analysis of woody flavouring from vine-shoots and oak chips. J. Sci. Food Agric. 2014, 94, 504-514. [CrossRef] [PubMed]

9. Cebrián, C.; Sánchez-Gómez, R.; Salinas, M.R.; Alonso, G.L.; Zalacain, A. Effect of post-pruning vine-shoots storage on the evolution of high-value compounds. Ind. Crops Prod. 2017, 109, 730-736. [CrossRef]

10. Houillé, B.; Besseau, S.; Courdavault, V.; Oudin, A.; Glévarec, G.; Delanoue, G.; Lanoue, A. Biosynthetic origin of e -resveratrol accumulation in grape canes during postharvest storage. J. Agric. Food Chem. 2015, 63, 1631-1638. [CrossRef]

11. Cebrián-Tarancón, C.; Sánchez-Goómez, R.; Gómez-Alonso, S.; Hermosín-Gutierrez, I.; Mena-Morales, A.; García-Romero, E.; Salinas, M.R.; Zalacain, A. Vine-shoot tannins: Effect of post-pruning storage and toasting treatment. J. Agric. Food Chem. 2018, 66, 5556-5562. [CrossRef]

12. Sánchez-Gómez, R.; Zalacain, A.; Alonso, G.L.; Salinas, M.R. Effect of toasting on non-volatile and volatile vine-shoots low molecular weight phenolic compounds. Food Chem. 2016, 204, 499-505. [CrossRef]

13. Cebrián-Tarancón, C.; Sánchez-Gómez, R.; Salinas, M.R.; Alonso, G.L.; Oliva, J.; Zalacain, A. Toasted vine-shoot chips as enological additive. Food Chem. 2018, 263, 96-103. [CrossRef]

14. Cebrián-Tarancón, C.; Sánchez-Gómez, R.; Carot, J.M.; Zalacain, A.; Alonso, G.; Salinas, M.R. Assessment of vine-shoots in a model wines as enological additives. Food Chem. 2019, 288, 86-95. [CrossRef]

15. Cebrián-Tarancón, C.; Sánchez-Gómez, R.; Cabrita, M.J.; García, R.; Zalacain, A.; Alonso, G.; Salinas, M.R. Winemaking with vine-shoots. Modulating the composition of wines by using their own resources. Food Res. Int. 2019, 121, 117-126. [CrossRef]

16. Bautista-Ortín, A.B.; Lencina, A.G.; Cano-López, M.; Pardo-Mínguez, F.; López-Roca, J.M.; Gómez-Plaza, E. The use of oak chips during the ageing of a red wine in stainless steel tanks or used barrels: Effect of the contact time and size of the oak chips on aroma compounds. Aust. J. Grape Wine Res. 2008, 14, 63-70. [CrossRef]

17. Kyraleou, M.; Teissedre, P.L.; Tzanakouli, E.; Kotseridis, Y.; Proxenia, N.; Chira, C.; Ligas, I.; Kallithraka, S. Addition of wood chips in red wine during and after alcoholic fermentation: Differences in color parameters, phenolic content and volatile composition. OENO One 2016, 50, 209-222. [CrossRef]

18. Laqui-Estaña, J.; López-Solís, R.; Peña-Neira, A.; Medel-Marabolía, M.; Obreque-Slier, E. Wines in contact with oak wood: The impact of the variety (Carménère and Cabernet Sauvignon), format (barrels, chips and staves), and aging time on the phenolic composition. J. Sci. Food Agric. 2019, 99, 436-448. [CrossRef] [PubMed]

19. Instituto Nacional de Vitivinicultura (INV). Informe Anual de Superficie 2020. Available online: https://www.argentina.gob.ar/ inv/vinos/estadisticas/superficie/anuarios (accessed on 19 May 2021).

20. Organisation Internationale de la Vigne et du Vin (OIV). Compendium of International Methods of Analysis of Wines and Musts; OIV: Paris, France, 2012; Volume 1.

21. Harbertson, J.F.; Picciotto, E.A.; Adams, D.O. Measurement of polymeric pigments in grape berry extracts and wines using a protein precipitation assay combined with bisulfite bleaching. Am. J. Enol. Vitic. 2003, 54, 301-306.

22. Heredia, T.M.; Adams, D.O.; Fields, K.C.; Held, P.G.; Harbertson, J.F. Evaluation of a comprehensive Red wine phenolics assay using a microplate reader. Am. J. Enol. Vitic. 2006, 57, 497-502.

23. Gordillo, B.; Rodríguez-Pulido, F.J.; Escudero-Gilete, M.L.; González-Miret, M.L.; Heredia, F.J. Comprehensive colorimetric study of anthocyanic copigmentation in model solutions. Effects of $\mathrm{pH}$ and molar ratio. J. Agric. Food Chem. 2012, 60, $2896-2905$. [CrossRef]

24. Commission Internationale de l'Eclairage (CIE). Technical Report Colorimetry; Commission Internationale de l'Eclairage Central Bureau; CIE: Vienna, Austria, 2004.

25. Gama, J. Colorscience: Color Science Methods and Data. R Package Version 1.0.8. Available online: http:/ /CRAN.R-project.org/ package $=$ colorscience (accessed on 1 April 2021).

26. Blanco-Vega, D.; López-Bellido, F.J.; Alía-Robledo, J.M.; Hermosín-Gutiérrez, I. HPLC-DAD-ESI-MS/MS characterization of pyranoanthocyanins pigments formed in model wine. J. Agric. Food Chem. 2011, 59, 9523-9531. [CrossRef]

27. Delarue, J. Flash Profile. In Novel Techniques in Sensory Characterization and Consumer Profiling, 1st ed.; Varela, P., Ares, A., Eds.; CRC Press: Boca Raton, FL, USA, 2014; pp. 175-205.

28. Lê, S.; Worch, T. Analyzing Sensory Data with R; CRC Press Taylor \& Francis Group: Boca Raton, FL, USA, 2014; 372p.

29. Husson, F.; Lê, S.; Cadoret, M. SensoMineR: Sensory Data Analysis. R Package Version 1.23. Available online: https:/ /CRAN.Rproject.org/package=SensoMineR (accessed on 20 April 2021).

30. Vivas, N.; Augustin, A.; Lonvaud-Funel, A. Influence of oak wood and grape tannins on the lactic acid bacterium Oenococcus oeni (Leuconostoc oenos, 8413). J. Sci. Food Agric. 2000, 80, 1675-1678. [CrossRef]

31. Dumitriu, G.D.; Peinado, R.A.; Coteac, V.V.; de Lerma, N.L. Volatilome fingerprint of red wines aged with chips or staves: Influence of the aging time and toasting degree. Food Chem. 2020, 310, 125801. [CrossRef]

32. Kilmister, R.L.; Mazza, M.; Baker, N.K.; Faulkner, P.; Downey, M.O. A role for anthocyanin in determining wine tannin concentration in Shiraz. Food Chem. 2014, 152, 475-482. [CrossRef]

33. Adams, D.O.; Harbertson, J.F.; Picciotto, E.A. Fractionation of Red Wine Polymeric Pigments by Protein Precipitation and Bisulfite Bleaching. In Red Wine Color; Waterhouse, A.L., Kennedy, J.A., Eds.; American Chemical Society: Washington, DC, USA, 2004; Volume 886, pp. 275-288. [CrossRef] 
34. Gordillo, B.; Cejudo-Bastante, M.J.; Rodríguez-Pulido, F.J.; Jara-Palacios, M.J.; Ramírez-Pérez, P.; González-Miret, M.L.; Heredia, F.J. Impact of adding white pomace to red grapes on the phenolic composition and color stability of Syrah wines from a warm climate. J. Agric. Food Chem. 2014, 62, 2663-2671. [CrossRef] [PubMed]

35. Fanzone, M.L.; Sari, S.E.; Mestre, M.V.; Catania, A.A.; Catelén, M.J.; Jofré, V.P.; González-Miret, M.L.; Combina, M.; Vazquez, F.; Maturano, Y.P. Combination of pre-fermentative and fermentative strategies to produce Malbec wines of lower alcohol and $\mathrm{pH}$, with high chemical and sensory quality. OENO One 2020, 54, 1041-1058. [CrossRef]

36. Martínez, J.A.; Melgosa, M.; Pérez, M.M.; Hita, E.; Negueruela, A.I. Note. Visual and instrumental color evaluation in red wines. Food Sci. Technol. Int. 2001, 7, 439-444. [CrossRef]

37. Pérez-Magariño, S.; González-Sanjosé, M.L. Application of absorbance values used in wineries for estimating CIELAB parameters in red wines. Food Chem. 2003, 81, 301-306. [CrossRef]

38. Fanzone, M.; Zamora, F.; Jofré, V.; Assof, M.; Gómez-Cordovés, C.; Peña-Neira, Á. Phenolic characterisation of red wines from different grape varieties cultivated in Mendoza province (Argentina). J. Sci. Food Agric. 2012, 92, 704-718. [CrossRef]

39. Canals, R.; Llaudy, M.C.; Canals, J.M.; Zamora, F. Influence of the elimination and addition of seeds on the colour, phenolic composition and astringency of red wine. Eur. Food Res. Technol. 2008, 226, 1183-1190. [CrossRef]

40. Casassa, L.F.; Dermutz, N.P.; Mawdsley, P.F.W.; Thompson, M.; Catania, A.A.; Collins, T.S.; Ashmore, P.L.; du Fresne, F.; Gasic, G.; Dodson Peterson, J.C. Whole cluster and dried stem additions effects on chemical and sensory properties of Pinot noir wines over two vintages. Am. J. Enol. Vitic. 2021, 72, 21-35. [CrossRef]

41. Baiano, A.; De Gianni, A.; Mentana, A.; Quinto, M.; Centonze, D.; Del Nobile, M.A. Effects of the treatment with oak chips on color-related phenolics, volatile composition, and sensory profile of red wines: The case of Aglianico and Montepulciano. Eur. Food Res. Technol. 2016, 242, 745-767. [CrossRef]

42. Gordillo, B.; Baca-Bocanegra, B.; Rodríguez-Pulido, F.J.; González-Miret, M.L.; Estévez, I.G.; Quijada-Morín, N.; Heredia, F.J.; Escribano-Bailón, M.T. Optimisation of an oak chips-grape mix maceration process. Influence of chip dose and maceration time. Food Chem. 2016, 206, 249-259. [CrossRef]

43. de Esteban, M.L.G.; Ubeda, C.; Heredia, F.J.; Catania, A.A.; Assof, M.V.; Fanzone, M.L.; Jofre, V.P. Impact of closure type and storage temperature on chemical and sensory composition of Malbec wines (Mendoza, Argentina) during aging in bottle. Food Res. Int. 2019, 125, 108553. [CrossRef]

44. Del Barrio-Galán, R.; Medel-Marabolí, M.; Peña-Neira, A. Effect of different aging techniques on the polysaccharide and phenolic composition and sensory characteristics of Syrah red wines fermented using different yeast strains. Food Chem. 2015, 179, 116-126. [CrossRef]

45. Del Álamo, S.M.; Escudero, J.A.F.; De Castro, T.R. Changes in phenolic compounds and colour parameters of red wine aged with oak chips and in oak barrels. Food Sci. Technol. Int. 2004, 10, 233-241. [CrossRef]

46. Pérez-Magariño, S.; González-San José, M.L. Evolution of flavanols, anthocyanins, and their derivatives during the aging of red wines elaborated from grapes harvested at different stages of ripening. J. Agric. Food Chem. 2004, 52, 1181-1189. [CrossRef] [PubMed]

47. Cadahía, E.; de Simón, B.F.; Sanz, M.; Poveda, P.; Colio, J. Chemical and chromatic characteristics of Tempranillo, Cabernet Sauvignon and Merlot wines from DO Navarra aged in Spanish and French oak barrels. Food Chem. 2009, 115, 639-649. [CrossRef]

48. Avizcuri, J.M.; Sáenz-Navajas, M.P.; Echávarri, J.F.; Ferreira, V.; Fernández-Zurbano, P. Evaluation of the impact of initial red wine composition on changes in color and anthocyanin content during bottle storage. Food Chem. 2016, 213, 123-134. [CrossRef] [PubMed]

49. Baiano, A.; De Gianni, A. Timing of the treatment with oak chips: The case of Nero di Troia wine. Eur. Food Res. Technol. 2016, 242, 1343-1353. [CrossRef]

50. Jordão, A.M.; Ricardo-da-Silva, J.M.; Laureano, O. Effect of oak constituents and oxygen on the evolution of malvidin-3-glucoside and (+)-catechin in model wine. Am. J. Enol. Vitic. 2006, 57, 377-381.

51. Rentzsch, M.; Schwarz, M.; Winterhalter, P. Pyranoanthocyanins-An overview on structures, occurrence, and pathways of formation. Trends Food Sci. Technol. 2007, 18, 526-534. [CrossRef]

52. Escribano-Bailón, T.; Álvarez-García, M.; Rivas-Gonzalo, J.C.; Heredia, F.J.; Santos-Buelga, C. Color and stability of pigments derived from the acetaldehyde-mediated condensation between malvidin 3-O-glucoside and (+)-catechin. J. Agric. Food Chem. 2001, 49, 1213-1217. [CrossRef]

53. Cadoret, M.; Husson, F. Construction and evaluation of confidence ellipses applied at sensory data. Food Qual. Prefer. 2013, 28, 106-115. [CrossRef] 